\title{
Niosomes of active Fumaria officinalis phytochemicals: antidiabetic, antineuropathic, anti-inflammatory, and possible mechanisms of action
}

\author{
Karim M. Raafat ${ }^{*}$ and Sally A. El-Zahaby ${ }^{2}$
}

\begin{abstract}
Background: Fumaria officinalis (F. officinalis, FO) has been used in many inflammatory and painful-ailments. The main aim of this work is to perform an in-depth bio-guided phytochemical investigation of F. officinalis by identifying its main-active ingredients. Optimizing pharmacokinetics via niosomal-preparation will also be done to enhance their in vivo antineuropathic and anti-inflammatory potentials, and to explore their possible-mechanism of actions.

Methods: Bio-guided phytochemical-investigations including fractionation, isolation, chromatographic-standardization, and identification of the most active compound(s) were done. Optimized niosomal formulations of $F$. officinalis most active compound(s) were prepared and characterized. An in vivo biological-evaluation was done exploring acute, subchronic, and chronic alloxan-induced diabetes and diabetic-neuropathy, and carrageenan-induced acute inflammatory-pain and chronic-inflammatory edema.

Results: In-vivo bio-guided fractionation and chromatographic phytochemical-analysis showed that the alkaloidrich fraction (ARF) is the most-active fraction. ARF contained two major alkaloids; Stylopine 48.3\%, and Sanguinarine 51.6\%. In-vitro optimization, analytical, and in vivo biological-investigations showed that the optimized-niosome, Nio2, was the most optimized niosomal formulation. Nio-2 had particle size $96.56 \pm 1.87 \mathrm{~nm}$ and worked by improving the pharmacokinetic-properties of ARF developing adequate entrapment-efficiency, rapid-degradation, and acceptable stability in simulated GI conditions. FO, ARF, and Nio 2 were the most potent antidiabetic and anti-inflammatory compounds. The reduction of the pro-inflammatory tumor necrosis factor-alpha (TNF-alpha) and Interleukin 6 (IL-6), and elevation the anti-inflammatory factor IL-10 levels and amelioration of the in vivo oxidative-stress might be the main-mechanism responsible for their antinociceptive and anti-inflammatory activities.
\end{abstract}

Conclusions: Fumaria officinalis most-active fraction was identified as ARF. This study offers an efficient and novel practical oral formulation ameliorating various inflammatory conditions and diabetic complications especially neuropathic-pain.

Keywords: Fumaria officinalis, Niosomes, HPLC-analysis, Antineuropathic, Anti-inflammatory

*Correspondence: k.raafat@bau.edu.lb

1 Department of Pharmaceutical Sciences, Faculty of Pharmacy, Beirut Arab University, Beirut 115020, Lebanon

Full list of author information is available at the end of the article

\section{Background}

During the last decade, there was a growing demand for natural plants having diverse activities towards diseases especially chronic ones that need long term management [1]. Fumaria officinalis, family Papaveraceae (Fumariaceae), also named "smoke of the earth" is a tiny 
plant that grows in many Eastern-Mediterranean countries. It has been used in the Asian folk-medicine in many inflammatory and painful ailments like conjunctivitis and rheumatism [2-5]. Additionally, researchers had proven its efficacy as an antioxidant, antiviral and antimicrobial agent [6]. The plant phytochemically comprises many secondary metabolites especially the isoquinoline alkaloids [7-9]. These alkaloids are determined in literature by diverse techniques mainly reversed Phase-HPLC methods [8]. The folk use of $F$. officinalis (Fumaria officinalis) in various chronic ailments, made it of interest to explore its effect on other inflammatory and metabolic disorders and their complications.

Diabetes mellitus is a chronic metabolic-syndrome distinguished by the blood glucose level elevation, which in-turn increases the oxidative stress leading to many complications like diabetic neuropathy $[10,11]$. Diabetic neuropathy is peripheral micro-vascular neuropathy in which sensory and motor nerves are affected leading to the progressive loss of sensation and is characterized by hyperalgesia and allodynia. Besides metabolic factors, ischemic factors and inflammation also contribute to the development of diabetic neuropathies. The oxidative stress can lead to activation of the inflammatory mediators like cytokinins which contributes to nerve hypoxia $[12,13]$.

Inflammation is a defensive mechanism against pathogenic-aggression or noxious-stimuli. Interleukin (IL)-6, TNF-alpha (tumor necrosis factor-alpha), and elevated oxidative stress play an important part in the acute painful inflammatory pathogenesis and its chronic complications like edema $[14,15]$.

Despite, the biological efficiency of some natural drugs, the application of pharmaceutical formulations might have a good impact on the overall activity of these drugs because of the improvement in pharmacokinetics. One of these formulations is the utilization of niosomes. L'Oreal developed and patented niosomes since the 1970s for cosmetic purposes [16]. Then researchers successfully developed plenty of niosomal drug delivery formulations in different disciplines [17-19]. Niosomes are microscopic vesicles made of nonionic surfactant and cholesterol that are formed upon hydration in aqueous media [20]. Niosomes are supremacy compared to liposomes mainly in terms of stability which originated from their nonionic surfactant composition. Moreover, niosomes are more economical, more easily prepared, and devoid of undesired solvents usage [20]. These vesicles can be thermodynamically stable if the formulator chooses the right surfactant mixtures and the proper stabilizer, which is usually cholesterol. Additionally, the temperature at which the vesicles form must be adjusted above the gel/liquid transition of the main lipid composition of niosomes [21]. Niosomes are nanoscopic vesicles that can hold both hydrophilic and lipophilic drugs and are used as either targeted carriers for drugs, hormones, and antigens to diverse body organs or to control the release of these agents [22].

The literature survey has shown that there are some in vitro preliminary experiments done on the anti-diabetic activity of $F$. officinalis [5, 23], but there is no comprehensive work on optimizing its pharmacokinetics, in vivo antineuropathic potentials and the phytochemicals responsible for its activity and their mechanisms of action.

Thus, the objective of this work is to perform an indepth bio-guided phytochemical investigation of $F$. officinalis identifying its main-active ingredients. Optimizing pharmacokinetics via niosomal-preparation will also be done to enhance their in vivo antineuropathic and antiinflammatory potentials, and exploring their possiblemechanism of actions.

\section{Materials and methods \\ Plant collection, extraction, and phytochemical standardization}

Fumaria officinalis (Papaveraceae) aerial parts (F. officinalis) were collected from Akkar district, Lebanon (N $34^{\circ}$ $33^{\prime} 08^{\prime \prime}$ E $36^{\circ} 11^{\prime} 49^{\prime \prime}$, Lat. 34.5521507 Lng. 36.1970030) on March 2019. The herb was authenticated by comparing it to a reference sample, and a representative sample was stored in the faculty herbarium under the voucher specimen number (PS-38-18) for future reference.

Fumaria officinalis was dried in shade and was extracted utilizing Centic sonicator (China) using ethanol $(80 \%)$ for $120 \mathrm{~min}$ in three rounds. The extract was then dried under vacuum utilizing the Buchi rotary-evaporator (Germany). The obtained dry extract was sonicated with $0.05 \mathrm{M} \mathrm{H}_{2} \mathrm{SO}_{4}$ then filtered. Furthermore, the filtrate was treated with $30 \% \mathrm{NH}_{4} \mathrm{OH}$, EtAc, and re-dried via rotary-evaporator. The dried extract was kept under $-40{ }^{\circ} \mathrm{C}$ until further utilization.

The extract was standardized using Agilent HPLC (Japan) apparatus. An RP-HPLC method was utilized comprising a degasser, a C-18 column, and a mobile phase consisted of ACN (40\%) and Triethylamine (60\%) and the flow rate was adjusted to $1 \mathrm{~mL} / \mathrm{min}$ utilizing a DAD-detector focusing on 254 and $280 \mathrm{~nm}$. The HPLC peaks were identified and quantified by comparing to standard calibration curves of reference standards, and standard steeping methods [24]. The main peaks were confirmed utilizing in-line fraction separator. Each fraction was then injected in Nano-ESI mass spectrometer to affirm the main active peaks. All standards and solvents (analytical-grade) were purchased from Merck (Germany). 
Bio-guided fractionation, isolation, and identification of the most active compound(s)/fraction

To find $F$. officinalis most active compound(s)/fraction, $F$. officinalis was fractionated utilizing a column chromatography method. The glass column $(500 \mathrm{~mm} \times 3000 \mathrm{~mm})$ utilized RP-silica gel as a stationary phase. A gradient mobile phase was utilized using a mixture of (A) acetonitrile and (B) triethylamine (0.1\%); starting with $100 \%$ $\mathrm{B}$, then $40 \% \mathrm{~A}$, and finally $100 \% \mathrm{~A}$. Two-hundred fractions were gathered, and each fraction was investigated for its hypoglycemic and antinociceptive effects. The most active compound(s)/fraction were identified utilizing a similar RP-HPLC method used for the standardization of the whole extract. Mass spectrometry, ${ }^{1} \mathrm{H}$ and ${ }^{13} \mathrm{C}$ NMR-spectroscopy of the most bioactive fraction was also measured in deuterated DMSO on a Bruker 300 NMR-spectrometer at room temperature. The most active compound(s)/fraction were used to formulate the niosomes formulations.

\section{Niosomes materials, preparation, and characterization}

Span 60 (S) and Brij 52 (B) were purchased from Merck (Germany). Cholesterol ( $\mathrm{CH}$, purity $98 \%$ ) was obtained from Amresco (USA). All other chemicals (analytical grade) were obtained from Merck (Germany).

Various niosomal-formulations were prepared by ether-injection method [25]. In brief, in ether-injection, Span 60 or Brij 52 and $\mathrm{CH}$ were dissolved in ether. This solution was gradually injected into warm phosphatebuffer saline $\left(\mathrm{pH}=7.4,65^{\circ} \mathrm{C}\right)$ comprising the most active fraction and rotating $(100 \mathrm{rpm})$ at a constant rate. Niosomal vesicles were formed after the removal of ether and stored in a refrigerator (Table 1).

Entrapment efficiency, vesicle-size, zeta potential, and in vitro profile release of the various niosomes were detected.

\section{Entrapment efficiency (EE)}

To determine the content of the $F$. officinalis (FO) most active fraction in the niosomal formulations, the unentrapped content was separated from the niosomes utilizing the membrane-dialysis method against buffer solution at $4{ }^{\circ} \mathrm{C}$ [25]. The vesicles were washed using phosphate buffered saline followed by $1 \mathrm{~h}$ centrifugation. The amount of entrapped FO was determined by lysis of the vesicles with absolute ethanol. The concentration of FO most active fraction in the resulting solution was measured utilizing RP-HPLC. The \% EE was determined using the following equation:

$$
\begin{aligned}
\% \mathrm{EE}= & \text { Amount of entrapped FO most active fraction } \\
& \times 100 / \text { Total amount }
\end{aligned}
$$

\section{Vesicle size and zeta potential}

The vesicle size and zeta potential of various niosomal formulations were investigated utilizing Malvern Zetasizer (UK) at ambient temperature [25]. After repeating the experiments three times, Z-average $(\mathrm{nm})$ and zeta potential $(\mathrm{mV})$ values were given as the mean \pm mean standard error (SEM).

\section{In vitro drug release}

The release of FO most active fraction from niosomal formulations was studied using membrane-dialysis. Half a milliliter of FO most active fraction-loaded niosomes was placed into cellulose membrane-dialysis which were then transferred to $50 \mathrm{~mL}$ of the release media $(\mathrm{pH}=6.8$, enzyme-free simulated intestinal fluid (SIF) containing Tween $80(0.1 \%, \mathrm{w} / \mathrm{v})$, to maintain the sink condition, and sodium taurocholate $(10 \mathrm{mM})$, to simulate bile-salt concentration in the small-intestine, as reported before in the literature [25]. To mimic the release system, the system was maintained at $37 \pm 0.5{ }^{\circ} \mathrm{C}$ was magneti-cally stirred at $100 \mathrm{rpm}$. Aliquots of release media $(1 \mathrm{~mL})$ were

Table 1 The composition and characteristics of the tested niosomal formulations

\begin{tabular}{lllllll}
\hline Code & Composition $^{\mathbf{a}}$ & Weight ratio & EE (\%) & Zeta potential $(\mathbf{m V})$ & Z-average (nm) $^{\text {PDI }^{\mathbf{b}}}$ \\
\hline Nio1 & S:CH & $1: 1$ & $91.25 \pm 2.80$ & $-53.06 \pm 2.40$ & $90.60 \pm 1.90$ & $0.30 \pm 0.01$ \\
Nio2 & S:CH & $2: 1$ & $94.65 \pm 3.33$ & $-56.75 \pm 2.60$ & $96.56 \pm 1.87$ & $0.34 \pm 0.02$ \\
Nio3 & S:CH & $3: 1$ & $92.56 \pm 4.21$ & $-58.10 \pm 3.10$ & $97.60 \pm 1.55$ & $0.36 \pm 0.01$ \\
Nio4 & S:B & $1: 1$ & $96.70 \pm 2.30$ & $-67.80 \pm 3.40$ & $93.56 \pm 2.22$ & $0.31 \pm 0.01$ \\
Nio5 & S:B & $2: 1$ & $98.22 \pm 1.44$ & $-65.38 \pm 3.20$ & $94.66 \pm 2.34$ & $0.33 \pm 0.02$ \\
Nio6 & S:B & $3: 1$ & $93.55 \pm 1.99$ & $-58.50 \pm 3.00$ & $98.7 \pm 1.22$ & $0.36 \pm 0.01$ \\
Placebo I & S:CH & $3: 1$ & - & $-25.70 \pm 2.45$ & $86.66 \pm 1.11$ & $0.28 \pm 0.02$ \\
Placebo II & S:B & $3: 1$ & - & $-24.60 \pm 2.68$ & $84.99 \pm 1.33$ & $0.27 \pm 0.01$ \\
\hline
\end{tabular}

\footnotetext{
a S Span 60, CH cholesterol, $B$ Brij 52
}

b $P D /$ poly-dispersity index 
removed, and replaced with fresh media, on a fixed intervals $(0,0.25,0.5,1.0,1.5$, and $3 \mathrm{~h})$, centrifuged, and examined utilizing the RP-HPLC method. This method was repeated three times and the average release was determined (mean \pm SEM).

\section{Niosomes stability in sodium taurocholate}

Under perfect sink conditions, the ability of FO active fraction-loaded niosomes to keep their physical-properties was tested when accompanied by sodium taurocholate (STC, $10 \mathrm{mM})$. Various niosomes were placed into SIF $\left(37^{\circ} \mathrm{C}\right)$ containing STC $(10 \mathrm{mM})$ and stirred (110 rpm). Placebo I (drug-free Nio 3) and Placebo II (drug-free Nio 6) were prepared and were investigated the same way as the FO active fraction-loaded niosomes.

Vesicular size, zeta potential, and poly-dispersity index (PDI) were measured prior to and directly after $10 \mathrm{~h}$ incubation utilizing Malvern Zeta-sizer (UK). The results were given as an average (mean \pm SEM) of three experimental replications.

\section{Animals and in vivo experiments}

Male Swiss albino mice (20-28 g) were used in the in vivo experiments. Animals had free entry to the water. Mice had free access to standard laboratory food. As for diabetes experiments, the mice were made to fast for $16 \mathrm{~h}$. Animals were exposed to $12 \mathrm{~h}$ dark-light cycles. The protocol of the experimental design ( $\mathrm{n}=7 /$ group) is summarized in (Table 2). Animal care for the research was done abiding by BAU Institutional Review Board regulations (2019A-0051-P-R-0341).

\section{Diabetes and diabetic-neuropathy biological evaluation}

Diabetes experiments were performed for $6 \mathrm{~h}$ (acute), 8 days (subchronic), and 8 weeks (chronic). The acute and the subchronic experiments were performed utilizing Sigma gluco-stripes and glucometers (Germany). The chronic studies were done utilizing Analyticon HbA1c mini-columns (Germany). The diabetes was provoked in mice by alloxan injection $(180 \mathrm{mg} / \mathrm{Kg})$ for 3 days. Mice having blood glucose levels $(\mathrm{BGL}) \geq 200 \mathrm{mg} / \mathrm{Kg}$ and HbA1c levels $\geq 8 \%$ were considered diabetic and were incorporated in the in vivo experiments [26].

Diabetic neuropathy was confirmed after 8 weeks of provoking diabetes with paw withdrawal thresholds less than $5 \mathrm{~g}$ [27]. The diabetic neuropathy (DN) symptoms of hyperalgesia were evaluated (in seconds) utilizing UgoBasile hot plate device (Italy) and Hugo-Sachs-Elektronik tail flick device (Germany) with a cut-off of 10S. DN symptoms of mechanical allodynia were measured (in grams) using Opti-hair Von Frey filaments (Germany) [28].

\section{Anti-diabetic and antinociceptive mechanism of action}

To understand the anti-diabetic and antinociceptive mechanism of action attributed to F. officinalis and its active phytochemicals, serum insulin level (SIL) was evaluated pre-administration and 8 weeks post-dosing. SIL was recorded prior-to and 8 weeks post-test administration using an Agilent HPLC device (Japan) and utilizing Merck reversed phase-C18 (Germany) with a one $\mathrm{ml} / \mathrm{min}$ flow-rate, and column temperature adjusted to $40{ }^{\circ} \mathrm{C}$ at $214 \mathrm{~nm}$. The gradient mobile phase was composed of acetonitrile (A) and $0.1 \%$ trifluoroacetic acid in Milli-Q water (B) and launched from 0 to 5 min 30\% (A) and then from 5 to 15 min 40\% (A) [29]. The inhibitory effects of the tested compounds on alpha-glucosidase inhibitory and alpha-amylase inhibitory potentials were determined in accordance with the methods described before [27]. Moreover, the elevated BGL increases the oxidative stress marked by the decrease of serum catalase levels (CAT), reduced glutathione levels (GSH), and elevate lipid peroxidase levels (LPO). This increase in oxidative stress was reported to be responsible for diabetes comorbidities like painful $\mathrm{DN}[30,31]$. Thus, the evaluation of antioxidant CAT, GSH, and LPO might give us insight into the $F$. officinalis antinociceptive mechanism of action. Furthermore, CAT levels were evaluated $(\mathrm{kU} / \mathrm{l})$ by a modified method described before [32]. Also, change in GSH levels were measured $(\mu \mathrm{g} / \mathrm{mg})$ at predose and 8 weeks post-oral-administration [33]. Also, LPO was evaluated utilizing TBARS (Thiobarbituric acid reactive substances) levels (nM/100 g) utilizing a modified method described previously using JASCOspectrophotometer (Japan) at $532 \mathrm{~nm}$ [34].

\section{Anti-inflammatory biological evaluation}

The anti-inflammatory activities of $F$. officinalis and its active phytochemicals/formulas were evaluated acutely via the carrageenan-induced inflammatory-pain method, and chronically via hind-paw edema method [35].

Acutely, the Merck carrageenan-solution $(100 \mu \mathrm{L}, 1 \%$ in saline, Germany) was injected into the left hind-paw intra-plantarly. The positive control, Ibuprofen $100 \mathrm{mg} /$ $\mathrm{Kg}$ (Ib), was orally dispensed $30.00 \pm 1.00 \mathrm{~min}$ before carrageenan-injection [36, 37]. The vehicle control mice $(\mathrm{VEH})$ administered saline $(100 \mu \mathrm{L})$ only prior to carrageenan-injection. The evaluation of behavior was done $2 \mathrm{~h}$ after carrageen-injection.

The hind-paw edema method was performed chronically utilizing a modified method described before [35]. In brief, after the oral administration of the active phytochemicals/ formulas, the volume of the carrageenan-injected paw edema was determined utilizing MRPP plethysmograph (China) after administration and $4 \mathrm{~h}$ afterward, utilizing a positive control, Ib $100 \mathrm{mg} / \mathrm{Kg}$. 
Table 2 Protocol of experimental design

\begin{tabular}{|c|c|c|c|}
\hline Groups & $\mathbf{n}$ & Tested substance(s) & Description \\
\hline \multicolumn{4}{|c|}{ A. Acute (6 h) and subchronic (8 days) effect of Fumaria officinalis (FO) on blood glucose levels } \\
\hline । & 7 & Control & Normal mice: Vehicle [sterile cold saline (0.9\%)], PO \\
\hline$\|$ & 7 & Diabetic Control & Diabetic mice: Vehicle, $\mathrm{PO}$ \\
\hline III & 7 & GB & Diabetic mice: GB 5 mg/kg, PO \\
\hline IV & 7 & FO & Diabetic mice: FO 50 mg/kg, PO \\
\hline V & 7 & FO & Diabetic mice: FO 100 mg/kg, PO \\
\hline $\mathrm{Vl}$ & 7 & FO & Diabetic mice: FO 200 mg/kg, PO \\
\hline VII & 7 & ARF & Diabetic mice: ARF 15 mg/kg, PO \\
\hline VIII & 7 & ARF & Diabetic mice: ARF 30 mg/kg, PO \\
\hline IX & 7 & ARF & Diabetic mice: ARF 60 mg/kg, PO \\
\hline$x$ & 7 & Placebo I & Diabetic mice: Placebo I (Nio 3), PO \\
\hline$X I$ & 7 & Nio 1 & Diabetic mice: ARF 60 mg/kg in Nio 1, PO \\
\hline XII & 7 & Nio 2 & Diabetic mice: ARF 60 mg/kg in Nio 2, PO \\
\hline$X I I I$ & 7 & Nio 3 & Diabetic mice: ARF 60 mg/kg in Nio 3, PO \\
\hline XIV & 7 & Placebo II & Diabetic mice: Placebo II (Nio 6), PO \\
\hline$X V$ & 7 & Nio 4 & Diabetic mice: ARF 60 mg/kg in Nio 4, PO \\
\hline$X V I$ & 7 & Nio 5 & Diabetic mice: ARF 60 mg/kg in Nio 5, PO \\
\hline$X V \|$ & 7 & Nio 6 & Diabetic mice: ARF 60 mg/kg in Nio 6, PO \\
\hline$X V I I I$ & 7 & Sty & Diabetic mice: Sty 7.5 mg/kg, PO \\
\hline XIX & 7 & Sty & Diabetic mice: Sty 15 mg/kg, PO \\
\hline$x X$ & 7 & Sty & Diabetic mice: Sty 30 mg/kg, PO \\
\hline$X X I$ & 7 & San & Diabetic mice: San 7.5 mg/kg, PO \\
\hline$X X \|$ & 7 & San & Diabetic mice: San 15 mg/kg, PO \\
\hline$X X I I I$ & 7 & San & Diabetic mice: San 30 mg/kg, PO \\
\hline
\end{tabular}

B. For longer time $(0,2,4,6$ and 8 weeks) effects on hot plate and tail withdrawal latencies, and von Frey paw withdrawal thresholds

\begin{tabular}{|c|c|c|c|}
\hline XXIII & 7 & Control & Normal mice: Vehicle [sterile cold saline (0.9\%)], PO \\
\hline XXIV & 7 & Vehicle Control & Diabetic mice: Vehicle, PO \\
\hline XXV & 7 & GB & Diabetic mice: GB 5 mg/kg, PO \\
\hline XXVI & 7 & FO & Diabetic mice: FO 50 mg/kg, PO \\
\hline$X X V I I$ & 7 & FO & Diabetic mice: FO 100 mg/kg, PO \\
\hline XXVIII & 7 & FO & Diabetic mice: FO 200 mg/kg, PO \\
\hline XXIX & 7 & ARF & Diabetic mice: ARF 15 mg/kg, PO \\
\hline XXX & 7 & ARF & Diabetic mice: ARF 30 mg/kg, PO \\
\hline XXXI & 7 & ARF & Diabetic mice: ARF 60 mg/kg, PO \\
\hline XXXII & 7 & Placebo I & Diabetic mice: Placebo I (Nio 3), PO \\
\hline XXXIII & 7 & Nio 1 & Diabetic mice: ARF 60 mg/kg in Nio 1, PO \\
\hline XXXIV & 7 & Nio 2 & Diabetic mice: ARF 60 mg/kg in Nio 2, PO \\
\hline XXXV & 7 & Nio 3 & Diabetic mice: ARF 60 mg/kg in Nio 3, PO \\
\hline$X X X V I$ & 7 & Placebo II & Diabetic mice: Placebo II (Nio 6), PO \\
\hline XXXVII & 7 & $\mathrm{NiO} 4$ & Diabetic mice: ARF 60 mg/kg in Nio 4, PO \\
\hline XXXVIII & 7 & Nio 5 & Diabetic mice: ARF 60 mg/kg in Nio 5, PO \\
\hline XXXIX & 7 & Nio 6 & Diabetic mice: ARF 60 mg/kg in Nio 6, PO \\
\hline XXXX & 7 & Sty & Diabetic mice: Sty 7.5 mg/kg, PO \\
\hline XXXXI & 7 & Sty & Diabetic mice: Sty 15 mg/kg, PO \\
\hline XXXXII & 7 & Sty & Diabetic mice: Sty 30 mg/kg, PO \\
\hline XXXXIII & 7 & San & Diabetic mice: San 7.5 mg/kg, PO \\
\hline XXXXIV & 7 & San & Diabetic mice: San 15 mg/kg, PO \\
\hline XXXXXXV & 7 & San & Diabetic mice: San 30 mg/kg, PO \\
\hline
\end{tabular}




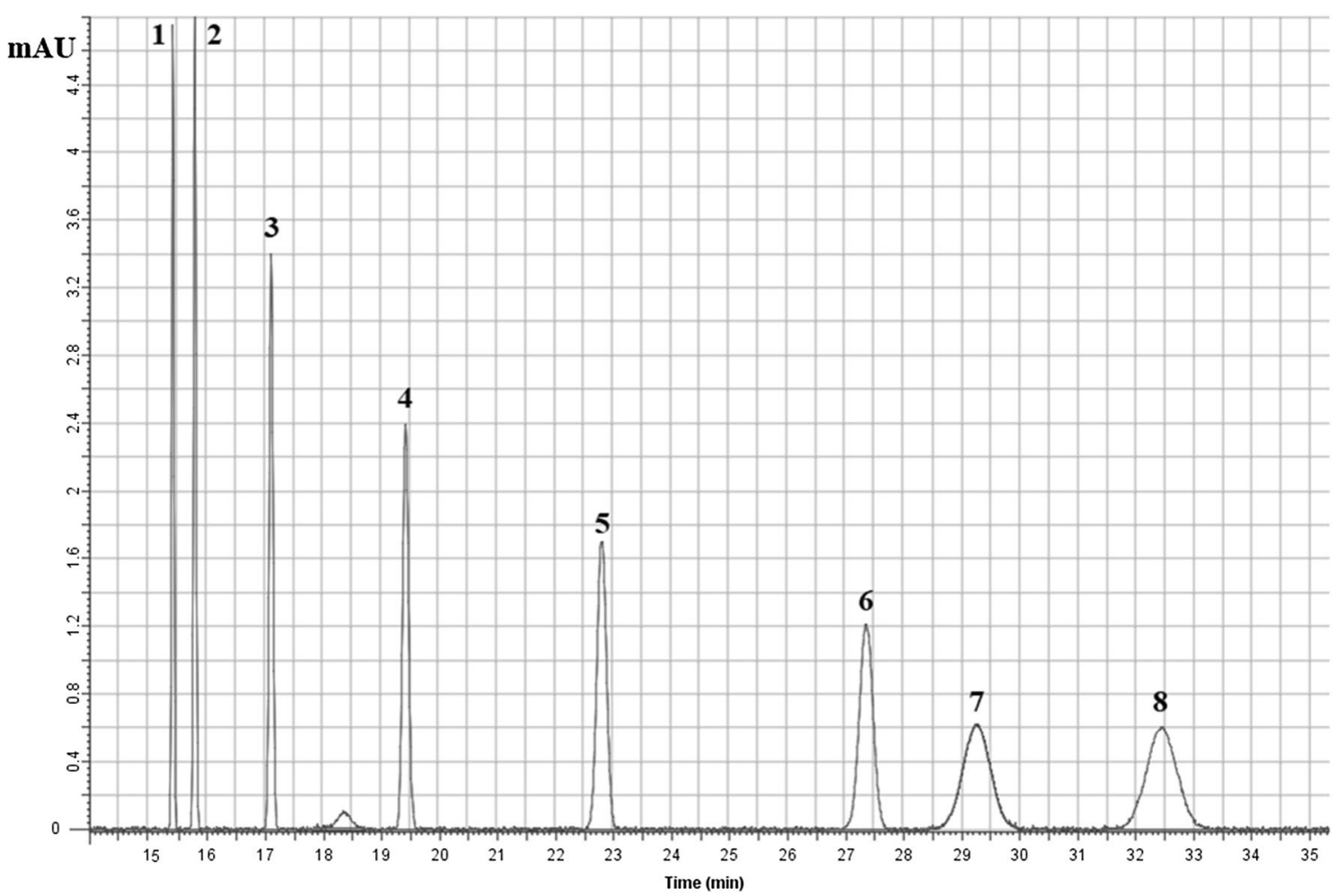

Fig. 1 Fumaria officinalis RP-HPLC major peaks: (1) Cheleritrine (9.2\%), (2) Hydrastine (10.7\%), (3) Bicuculline (11.2\%), (4) Protopine (12.3\%), (5) Chelidonine (13.2\%), (6) Allocryptopine (13.8\%), (7) Stylopine (14.3\%), and (8) Sanguinarine (15.3\%). The mobile phase consisted of ACN (40\%) and Triethylamine (60\%) and the flow rate was $1 \mathrm{~mL} / \mathrm{min}$ utilizing DAD detector focusing on 254 and $280 \mathrm{~nm}$

\section{The anti-inflammatory mechanism of action}

To understand the anti-inflammatory mechanism of action attributed to F. officinalis and its active phytochemicals, the level of inflammatory-mediators was determined. After centrifugation of the tissue-homogenates, the cytokines were measured in the supernatant using TNF-alpha, IL-6, and IL-10 (Bio-Legend, USA) enzyme-linked immune-sorbent assay (ELISA) kits [38].

\section{Statistical analysis}

Statistical analyses were done with OriginPro (USA). Data are shown as the mean \pm SEM. Comparison of the pharmacokinetic-parameters and the formulations were performed utilizing analysis-of-variance. In vivo experiments were statistically evaluated by one way ANOVA followed up with the Student-Newman-Keuls analysis. $P$ $<0.05$ was regarded as statistically-significant.

\section{Results}

Bio-guided phytochemical investigation

Utilizing the RP-HPLC method, the F. Officinalis extract (FO) was standardized. The FO HPLC chromatogram has shown that it contains 8 major peaks:
(2) Hydrastine
$(10.7 \%)$

Bicuculline (11.2\%) (4) Protopine (12.3\%), (5) Chelidonine (13.2\%), (6) Allocryptopine (13.8\%), (7) Stylopine (14.3\%), and (8) Sanguinarine (15.3\%) (Fig. 1).

A preliminary in vivo bio-guided phytochemical screening assay was performed on about 200 fractions isolated from FO. The bio-guided phytochemical screening assay has shown that the most active fraction, possessing comparable in vivo results to that of $\mathrm{FO}$, is rich in alkaloids, hence named the alkaloidrich fraction (ARF). The RP-HPLC investigation utilizing standard steeping and calibration curves method has shown that ARF contains 2 major peaks: Stylopine (Sty, 48.3\%), and (II) Sanguinarine (San, 51.6\%) (Figs. 2 and 3). Moreover, fractionation of ARF has been performed using flash chromatography and Sty and San were isolated and identified chromatographically. These findings were confirmed utilizing in-line fraction separator and positive Nano-ESI-MS/MS system (Mwt: Sty, $324.3 \mathrm{~g} / \mathrm{mol}$, and San, $333.09 \mathrm{~g} / \mathrm{mol}) .{ }^{1} \mathrm{H}$ and ${ }^{13} \mathrm{C}$ NMR have confirmed that Sty and San are the most active compounds in ARF (Table 3). 


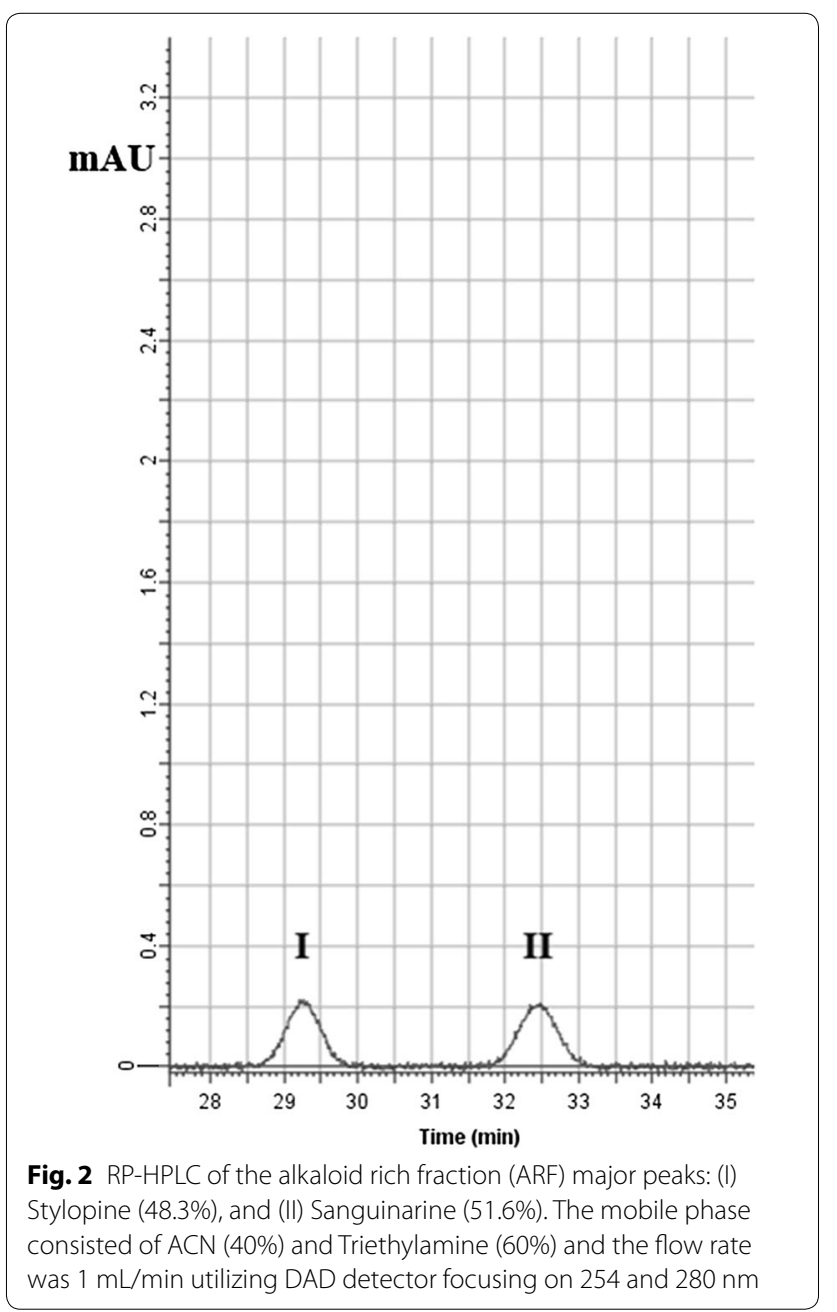

\section{Niosomes optimization}

Preliminary studies for niosome formulations were performed using different types of surfactants, surfactants ratio and preparation methodology. Cholesterol is reported to help acquiring homogeneity for the niosomal dispersions so it is included in all the prepared formulations [39]. Composition and method of preparation of niosomes were then chosen based on the obtained in vitro release pattern and the physicochemical properties of FO most active fraction, ARF. A series of formulations were prepared, alter-ing both surfactants and Cholesterol $(\mathrm{CH})$ content while preserving the other factors unchanged. The best surfactants that enhanced ARF in vitro release pattern were span 60 and Brij 52. The best method of niosome preparation was found to be the ether injection method that enabled the highest entrapment efficiency (EE). Thus, six ARF preparations (Nio 1-6) were prepared utilizing $\mathrm{CH}$ and either span 60 or Brij 52byether injection method. As shown in Table 3, all niosomes yielded high EE in the range from $91.25 \pm 2.80$ to $98.22 \pm 1.44$. The size of niosomal preparations ranged from $84.99 \pm 1.33$ to $98.7 \pm 1.22 \mathrm{~nm}$ with PDI in the range of $0.27 \pm 0.01$ to $0.36 \pm 0.01$, which is accepted and indicated homogeneity of the prepared formulations [40]. Comparing Nio 1 with Nio 4, it is obvious that Span 60 yielded smaller vesicles size than Brij 52, this can be explained based on the fact that surfactants having longer alkyl chains usually form larger niosomal vesicles [41].

Zeta-potential measurements were $-24.60 \pm 2.68$ to $-67.80 \pm 3.40 \mathrm{mV}$ indicating very good stability [42]. The observed negative charge was owing to hydroxylions adsorption on the niosomal surface as previously reported [25, 43].

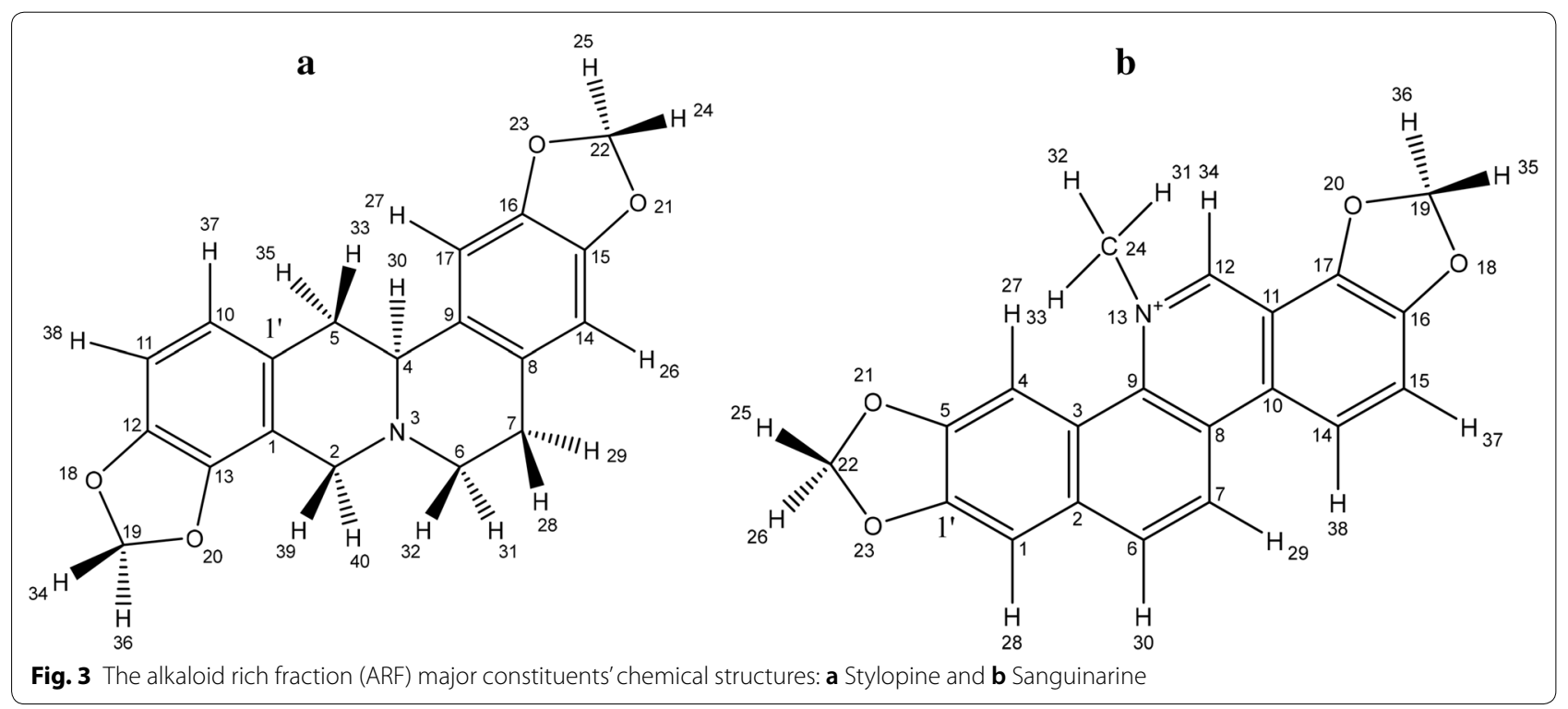


Table $3{ }^{1} \mathrm{H}$-NMR and ${ }^{13} \mathrm{C}$ - NMR data

\begin{tabular}{|c|c|c|c|c|}
\hline Structure & Position & $\delta C$ & Position & $\delta \mathrm{H}, \mathrm{m},(\mathrm{J}$ in Hz) \\
\hline \multirow[t]{24}{*}{ Stylopine ${ }^{a}$} & 1 & 120.8 & 24 & $5.93, \mathrm{~d}(J=10.62 \mathrm{~Hz})$ \\
\hline & $1^{\prime}$ & 133.2 & 25 & $5.92, d(J=10.61 \mathrm{~Hz})$ \\
\hline & 2 & 53.7 & 26 & $6.54, d(J=0.44 \mathrm{~Hz})$ \\
\hline & 3 & - & 27 & $6.29, \mathrm{~d}(J=0.43 \mathrm{~Hz})$ \\
\hline & 4 & 58.9 & 28 & $2.72, \mathrm{ddd}(J=13.46,10.18,3.41 \mathrm{~Hz})$ \\
\hline & 5 & 36.1 & 29 & $2.83, \mathrm{ddd}(J=13.46,3.41,2.23 \mathrm{~Hz})$ \\
\hline & 6 & 51.2 & 30 & $4.03, \mathrm{dd}(J=10.15,3.49 \mathrm{~Hz})$ \\
\hline & 7 & 28.5 & 31 & 2.69, ddd $(J=13.96,10.18,3.14 \mathrm{~Hz})$ \\
\hline & 8 & 127.3 & 32 & $3.04, \mathrm{ddd}(J=13.96,3.41,2.23 \mathrm{~Hz})$ \\
\hline & 9 & 129.8 & 33 & $2.76, \mathrm{dd}(J=13.34,3.49 \mathrm{~Hz})$ \\
\hline & 10 & 126.3 & 34 & $5.85, \mathrm{~d}(J=10.51 \mathrm{~Hz})$ \\
\hline & 11 & 108.1 & 35 & $2.78, \mathrm{dd}(J=13.33,10.15 \mathrm{~Hz})$ \\
\hline & 12 & 145.3 & 36 & $5.92, \mathrm{~d}(J=10.52 \mathrm{~Hz})$ \\
\hline & 13 & 142.7 & 37 & $6.42, d(J=8.62 \mathrm{~Hz})$ \\
\hline & 14 & 108.0 & 38 & 6.37, $d(J=8.61 \mathrm{~Hz})$ \\
\hline & 15 & 147.3 & 39 & $3.89, \mathrm{~d}(J=11.90 \mathrm{~Hz})$ \\
\hline & 16 & 145.1 & 40 & $3.87, \mathrm{~d}(J=11.91 \mathrm{~Hz})$ \\
\hline & 17 & 109.5 & & \\
\hline & 18 & - & & \\
\hline & 19 & 101.4 & & \\
\hline & 20 & - & & \\
\hline & 21 & - & & \\
\hline & 22 & 101.2 & & \\
\hline & 23 & - & & \\
\hline \multirow{25}{*}{$\begin{array}{l}\text { Sanguinar- } \\
\text { ine }^{\mathrm{a}}\end{array}$} & 1 & 106.3 & 25 & $33.32, \mathrm{~d}(J=15.50 \mathrm{~Hz})$ \\
\hline & $1^{\prime}$ & 148.7 & 26 & $33.33, \mathrm{~d}(J=15.50 \mathrm{~Hz})$ \\
\hline & 2 & 132.9 & 27 & $7.65, \mathrm{t}(J=0.44 \mathrm{~Hz})$ \\
\hline & 3 & 128.2 & 28 & $7.64, \mathrm{dt}(J=1.55,0.44 \mathrm{~Hz})$ \\
\hline & 4 & 106.3 & 29 & $8.10, \mathrm{dt}(J=6.19,0.43 \mathrm{~Hz})$ \\
\hline & 5 & 148.0 & 30 & $8.12, \mathrm{ddd}(J=6.19,1.55,0.46 \mathrm{~Hz})$ \\
\hline & 6 & 126.7 & 31 & $4.19, \mathrm{~s}$ \\
\hline & 7 & 126.5 & 32 & $4.18, \mathrm{~s}$ \\
\hline & 8 & 128.5 & 33 & $4.19, \mathrm{~s}$ \\
\hline & 9 & 138.4 & 34 & $9.71, \mathrm{~d}(J=0.55 \mathrm{~Hz})$ \\
\hline & 10 & 130.0 & 35 & $6.51, d(J=15.50 \mathrm{~Hz})$ \\
\hline & 11 & 116.7 & 36 & $6.50, \mathrm{~d}(J=15.51 \mathrm{~Hz})$ \\
\hline & 12 & 144.2 & 37 & $7.03, d(J=8.81 \mathrm{~Hz})$ \\
\hline & 13 & - & 38 & $8.53, \mathrm{ddd}(J=8.83,0.55,0.44 \mathrm{~Hz})$ \\
\hline & 14 & 126.1 & & \\
\hline & 15 & 114.8 & & \\
\hline & 16 & 147.4 & & \\
\hline & 17 & 142.5 & & \\
\hline & 18 & - & & \\
\hline & 19 & 101.1 & & \\
\hline & 20 & - & & \\
\hline & 21 & - & & \\
\hline & 22 & 101.3 & & \\
\hline & 23 & - & & \\
\hline & 24 & 46.1 & & \\
\hline
\end{tabular}

${ }^{a}$ Figure 2
The in vitro drug release from niosomal formulations In-vitro release study was performed to identify the influence of formulations optimization on the drug release rate from the niosomal-carriers. The cumulative release of ARF from Nio 1-6 were illustrated in Fig. 4. The cumula-tive drug release was approximately: Nio 1 (40.01 $\pm 1.72 \%)$, Nio 2 (88.12 $\pm 3.43 \%)$, Nio 3 (79.22 $\pm 3.71 \%)$, Nio $4(38.24 \pm 1.69 \%)$, Nio 5 $(69.98 \pm 3.39 \%)$, and Nio $6(64.88 \pm 3.79 \%)$, within $3 \mathrm{~h}$ (Fig. 4). It is obvious that increasing Span 60 (Nio 2 and 3) had increased the release of ARF compared to Nio 1. This could be attributed to the solubilizing power of Span 60 which facilitated the drug dispersion into the release media.

\section{Niosomes stability in sodium taurocholate}

The ability of ARF-loaded niosomes to retain their physical properties in the presence of sodium taurocholate under perfect sink conditions was investigated. Nio 1-6 were positioned into a pre-warmed release medium (enzyme-free) containing sodium taurocholate $(10 \mathrm{mM})$ and was stirred $(110 \mathrm{rpm})$ at $37^{\circ} \mathrm{C}$.

Vesicular size distributions, zeta potential, and polydispersity index (PDI) were measured prior to and directly after $10 \mathrm{~h}$ incubation utilizing Malvern Zetasizer (UK). The results of the influence of bile salts on the stability of ARF-loaded niosomes after incubation are described in Fig. 5. As shown in Fig. 5a, significant decreases $(P<0.05)$ in particle size (Z-average) were observed in Nio 2, Nio 3, Nio 5, Nio 6, and placebo 1 and II. Tween 80 and STC diffusion through dialysis membrane might enable them to reach the niosomal formulations affecting their physicochemical-characteristics, as described before in the literature [25]. On the other hand, there were no significant differences in $\mathrm{z}$-average in Nio 1 and Nio 4, which indicated stability of all formulations after incubation in STC. Furthermore, after $10 \mathrm{~h}$ incubation, no significant changes of PDI in Tween 80 alone or with STC were observed that ensured stability of the vesicles and that they preserved their acceptable range for oral delivery (Fig. 5b). Zeta-potentials are shown in Fig. 5c, where, no significant changes were observed in their values. This means that optimization of the prepared niosomal formulations had succeeded in their protection against harsh gastrointestinal conditions. This conclusion was based on the collective measurements of particle size, Zeta potential and PDI, where, the particle size was still within the acceptable range, Zeta potential values were sufficiently high and PDI values indicated homogenous distribution of the formed niosomes. The results were also within the allowed ranges for oral delivery, as described previously with similar dispersions [25]. 


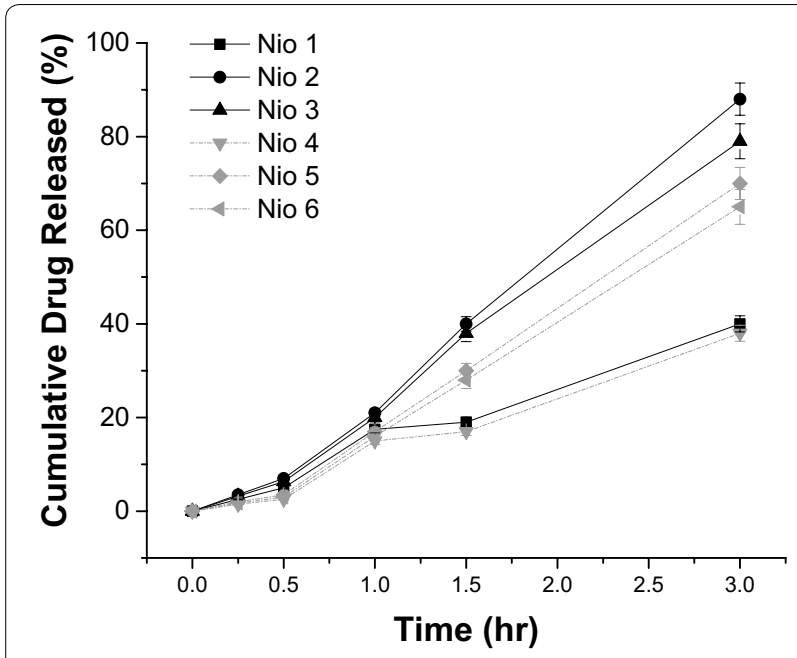

Fig. 4 In-vitro release pattern of alkaloid rich fraction (ARF) from different niosomes (mean \pm SEM)

\section{In-vivo diabetes and diabetic-neuropathy biological evaluation}

The anti-diabetic potentials of the tested compounds were evaluated acutely for $6 \mathrm{~h}$ (Fig. 6), subchronically for 8 days (Fig. 7) utilizing Sigma glucometers (Germany), and chronically for 8 weeks (Fig. 8) using Analyticon HbA1c mini-columns (Germany).

Acutely, Fumaria officinalis (FO) has shown a significant $\left(P^{<} 0.05\right)$ and dose dependent hypoglycemic activity, when compared to vehicle control diabetic mice (DC). After $6 \mathrm{~h}$ of oral administration, FO (50, 100, and $200 \mathrm{mg} / \mathrm{Kg}$ ) have shown 43.64, 45.45, and $46.36 \%$ reduction in blood glucose level (BGL), respectively (Fig. 6a). Moreover, FO most active fraction, ARF, has shown comparatively more significant $(P<0.05)$ BGL reduction than FO. After $6 \mathrm{~h}$ of oral administration, ARF (15, 30 , and $60 \mathrm{mg} / \mathrm{Kg}$ ) have shown 45.54, 46.63, and 47.27\% BGL reduction, respectively (Fig. 6a). Furthermore, ARF components stylopine (Sty), and sanguinarine (San) have been tested the same way as ARF. After $6 \mathrm{~h}$ of oral administration, Sty $(7.5,15$, and $30 \mathrm{mg} / \mathrm{Kg})$ have shown 34.10 , 36.64 , and $37.72 \%$ BGL reduction, respectively, while that of San $(7.5,15$, and $30 \mathrm{mg} / \mathrm{Kg}$ ) have shown $36.36,37.27$, and $38.63 \%$ BGL reduction, respectively (Fig. 6a). These results indicate that $\mathrm{ARF}$, acutely, has the most superior antidiabetic activity when compared to FO, ARF individual components (Sty and San), and the positive control, Glibenclamide (GB) (Fig. 6a). Thus, to observe the optimization effects of various niosomal formulations (Nio 1-6), ARF was utilized to be the active ingredient in these dispersions and was tested the same way as ARF. The doses of Nio 1-6 were adjusted to contain equivalent amounts of the highest dose of ARF $(200 \mathrm{mg} / \mathrm{Kg})$.

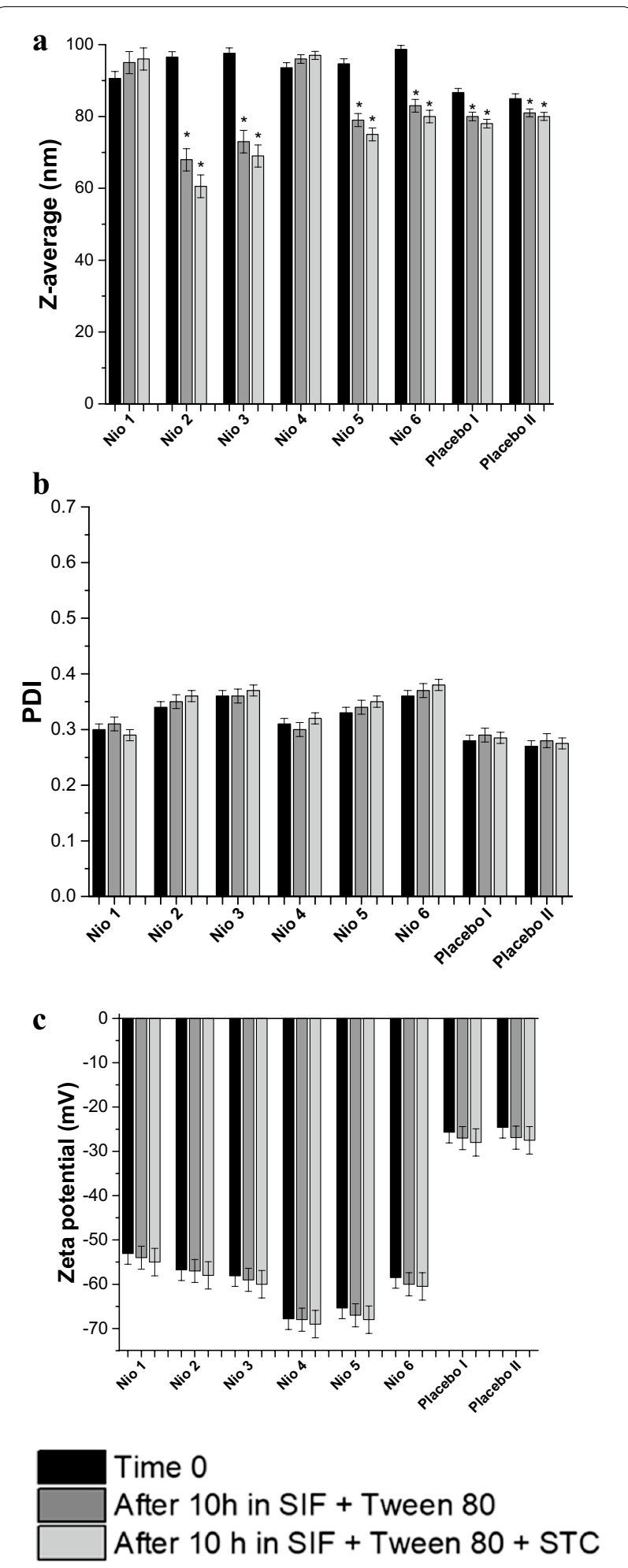

Fig. 5 Different niosomal formulations before and after $10 \mathrm{~h}$ incubation at $37^{\circ} \mathrm{C}$ in SIF with bile salts: a Z-average (nm), b PDI, and c Zeta potential $(\mathrm{mV})$. Data represent the mean $\pm \operatorname{SEM}(n=3)$. Where SIF is the simulated intestinal fluid and STC is sodium taurocholate. ${ }^{*} P$ value $<0.05$ versus time 0 

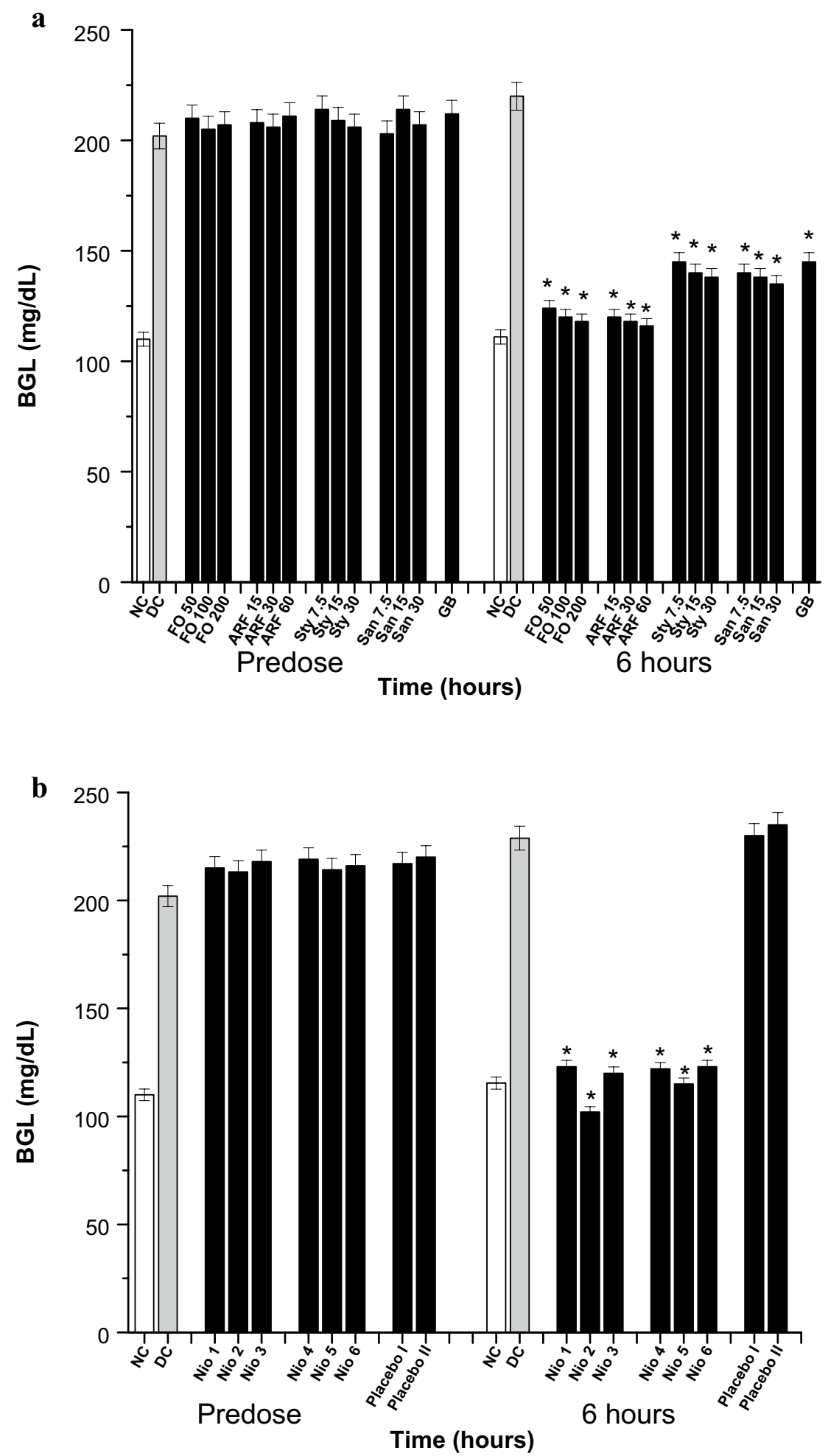

Fig. 6 Acute BGL. All doses are in (mg/Kg). a The acute effects of FO, ARF, Sty and San various doses utilizing Glibenclamide $5 \mathrm{mg} / \mathrm{Kg}$ (GB) as a positive control. $\mathbf{b}$ The acute effects of Nio 1-6 and placebo I and II. Asterisks designate significant results $(\mathrm{p}<0.05)$ when compared to diabetic control (DC). NC designates normal non-diabetic control 

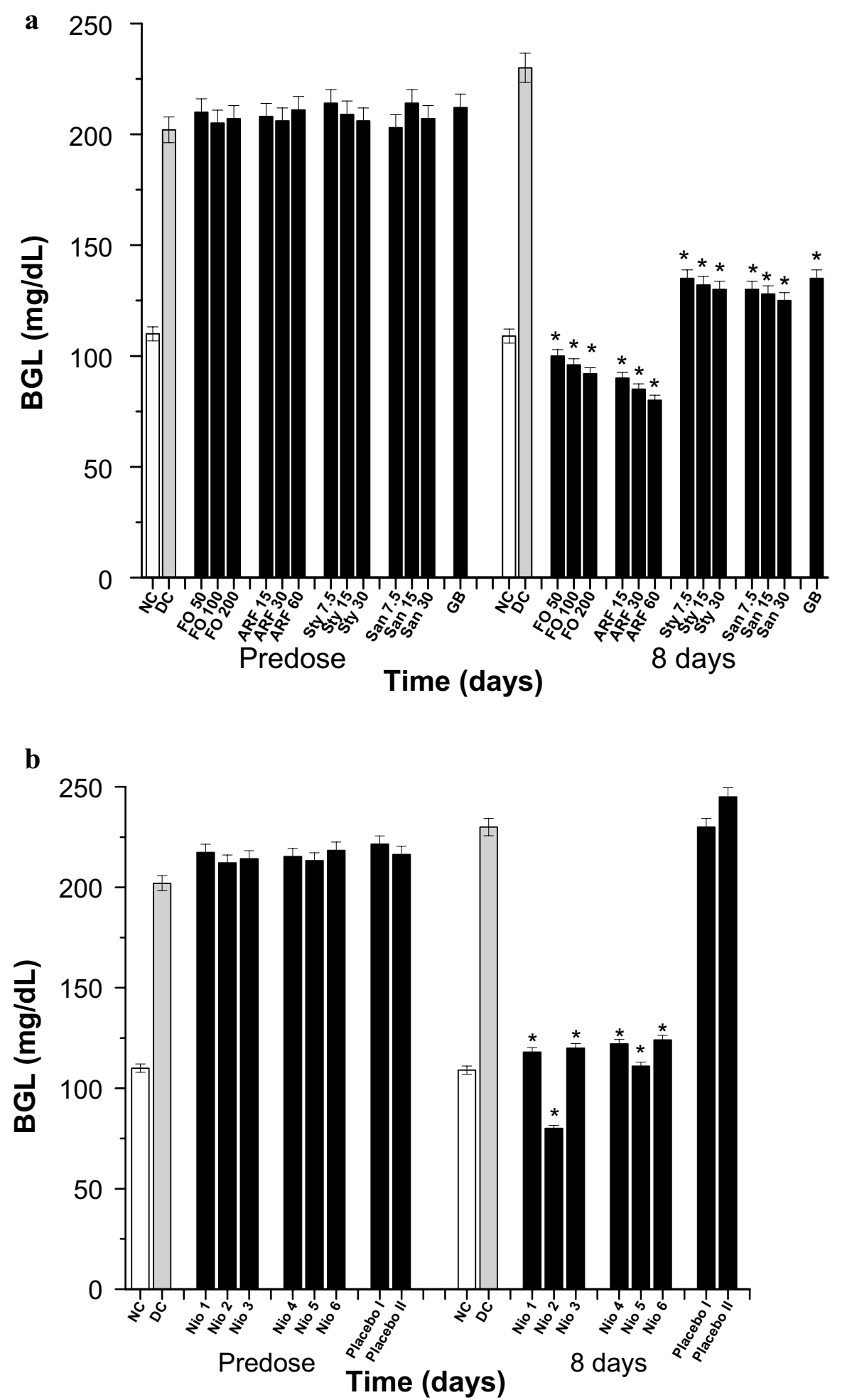

Fig. 7 Subchronic BGL. All doses are in (mg/Kg). a The subchronic effects of FO, ARF, Sty and San various doses utilizing Glibenclamide $5 \mathrm{mg} / \mathrm{Kg}$ (GB) as a positive control. $\mathbf{b}$ The subchronic effects of Nio 1-6 and placebo I and II. Asterisks designate significant results $(p<0.05)$ when compared to diabetic control (DC). NC designates normal non-diabetic control 
Placebo I (Nio 3 deprived of ARF) and placebo II (Nio 6 deprived of ARF) niosomes were also tested, as a negative control (Fig. 6b). After $6 \mathrm{~h}$ of oral administration, Nio 1, Nio 2, Nio 3, Nio 4, Nio 5, and Nio 6 have shown 46.24, 55.42, 47.55, 46.68, 49.74, and 46.42\% BGL reduction, respectively (Fig. 6b). Placebo I and II did not show any significant hypoglycemic activity, implying the efficiency of these formulations and that the formula improved the pharmacokinetics without having any anti-diabetic effects (Fig. 6b).

Subchronically, FO has shown a significant $(P<0.05)$ and dose dependent hypoglycemic activity, when compared to DC. As after 8 days of oral administration, FO (50, 100, and $200 \mathrm{mg} / \mathrm{Kg}$ ) have shown 56.52, 58.26, and $60.10 \%$ reduction in blood glucose level (BGL), respectively (Fig. 7a). Additionally, ARF has shown comparatively more significant $(P<0.05)$ BGL reduction than FO. As after 8 days of oral administration, $\operatorname{ARF}(15,30$, and $60 \mathrm{mg} / \mathrm{Kg}$ ) have shown $60.87,63.04$, and $65.21 \%$ BGL reduction, respectively (Fig. 7a). In addition, Sty (7.5, 15 , and $30 \mathrm{mg} / \mathrm{Kg}$ ) have shown $41.30,42.61$, and $43.48 \%$ $B G L$ reduction, respectively, whilst that of San $(7.5,15$, and $30 \mathrm{mg} / \mathrm{Kg}$ ) have shown 43.47, 44.35, and $45.65 \% \mathrm{BGL}$ reduction, respectively (Fig. 7a). These results strengthen the acute findings that ARF has the most superior antidiabetic activity when compared to FO, Sty, San, and GB (Fig. 7a). Furthermore, Nio-1, Nio-2, Nio-3, Nio-4, Nio-5, and Nio-6 have shown 48.70, 65.22, 47.82, 46.96, 51.74, and $46.09 \%$ BGL reduction, respectively (Fig. 7b). Placebo I and II also did not show any significant hypoglycemic activity, implying the efficiency of these formulations and that the formula improved the pharmacokinetics without having any anti-diabetic effects (Fig. 7b).

Chronically, the effect of the tested compounds was monitored for their changes in HbA1c (\%) levels prior to and 8 weeks after test compounds' administration in the diabetic groups (Fig. 8). FO has shown a significant $(P<$ 0.05 ) and dose dependent normalization of HbA1c levels when compared to DC (Fig. 8a). After 8 weeks of FO administration, FO $(50,100$, and $200 \mathrm{mg} / \mathrm{Kg}$ ) have shown 15.25, 18.08, and 20.90\% HbA1c level reduction (Fig. 8a). Additionally, ARF has shown comparatively more significant $(P<0.05)$ HbA1c level reduction than FO. As after 8 weeks of oral administration, $\operatorname{ARF}(15,30$, and $60 \mathrm{mg} /$ $\mathrm{Kg}$ ) have shown $18.09,19.49$, and $22.03 \% \mathrm{HbA1c}$ level reduction, respectively (Fig. 8a). Furthermore, Sty (7.5, 15 , and $30 \mathrm{mg} / \mathrm{Kg}$ ) have shown $10.73,11.86$, and $13.00 \%$ HbA1c level reduction, respectively, whilst that of San (7.5, 15, and $30 \mathrm{mg} / \mathrm{Kg}$ ) have shown $11.86,12.98$, and $15.25 \%$ HbA1c level reduction, respectively (Fig. 8a). These results strengthen the previous findings that ARF has the most superior antidiabetic activity when compared to FO, Sty, San, and GB (Fig. 8a). Moreover, Nio-1,
Nio-2, Nio-3, Nio-4, Nio-5, and Nio-6 have shown ca. 10.73, 22.03, 9.60, 11.86, 10.73, and 8.47\% HbA1c level reduction, respectively (Fig. $8 \mathrm{~b}$ ). As expected, placebo I and II did not show any significant HbA1c level changes (Fig. 8b).

\section{Anti-diabetic mechanism of action}

In order to explore the mechanism of actions underlying the tested compounds anti-diabetic activity, the serum insulin levels (SIL) of the various diabetic groups were monitored prior to and 8 weeks post-test compounds administration (Fig. 9). After 8 weeks of FO administration, FO $(50,100$, and $200 \mathrm{mg} / \mathrm{Kg})$ have shown 106, 120, and 130 fold increase in SIL (Fig. 9a). Furthermore, ARF $(15,30$, and $60 \mathrm{mg} / \mathrm{Kg})$ have shown ca. 131, 134, and 136 fold increase in SIL, respectively (Fig. 9a). Additionally, Sty $(7.5,15$, and $30 \mathrm{mg} / \mathrm{Kg}$ ) have shown ca. 46,50 , and 54 fold increase in SIL, respectively, whilst that of San $(7.5,15$, and $30 \mathrm{mg} / \mathrm{Kg}$ ) have shown ca. 38,62 , and 70 fold increase in SIL, respectively (Fig. 9a). These results imply that FO and ARF have potential antidiabetic activities and that their insulin-secretagogue potentials might be responsible for their hypoglycemic activities. Both FO and ARF have shown a dose dependant alpha-amylase and alpha-glucosidase inhibitory effects (Table 2). Also, Nio-1, Nio-2, Nio-3, Nio-4, Nio-5, and Nio-6 have shown ca. 118, 146, 106, 102, 110, and 101 fold increases in SIL, respectively (Fig. 9b). Placebo I and II did not show any significant SIL changes (Fig. 9b).

\section{Diabetic-neuropathy biological evaluation}

After 8 weeks of stimulation of diabetes, the diabetic animals were tested for symptoms of diabetic neuropathy. Diabetic animals with paw withdrawal thresholds less than $5 \mathrm{~g}$ were considered neuropathic and were included in the experiments [27]. The diabetic neuropathy symptoms of hyperalgesia (assessed by hot-plate and tail flick experiments) (Figs. 10 and 11) and allodynia (assessed by Von Frey filaments) (Fig. 12) were monitored chronically for 8 weeks post diabetic neuropathy symptoms provoking. Tramadol $10 \mathrm{mg} / \mathrm{Kg}$ (TRA) was utilized as a positive control. The tested compounds were given every other day for 8 weeks to assess their effects on symptoms of diabetic neuropathy (Figs. 10, 11, 12).

When compared to vehicle-treated group (VEH), the highest doses of FO $(200 \mathrm{mg} / \mathrm{Kg})$, ARF $(60 \mathrm{mg} / \mathrm{Kg})$, Sty $(30 \mathrm{mg} / \mathrm{Kg})$, and San $(30 \mathrm{mg} / \mathrm{Kg}$ ) have shown 82.22 , $88.89,79.99,68.89 \%$, respectively, improvement in hotplate latency (Fig. 10a), and ca. 11.5, 18.7, 6.9, 5.4 fold respectively, improvement in tail-flick latency (Fig. 11a), 8 weeks post-administration. These results showed that FO and ARF had potential anti-hyperalgesic potentials, as shown previously with similar compounds [44]. 

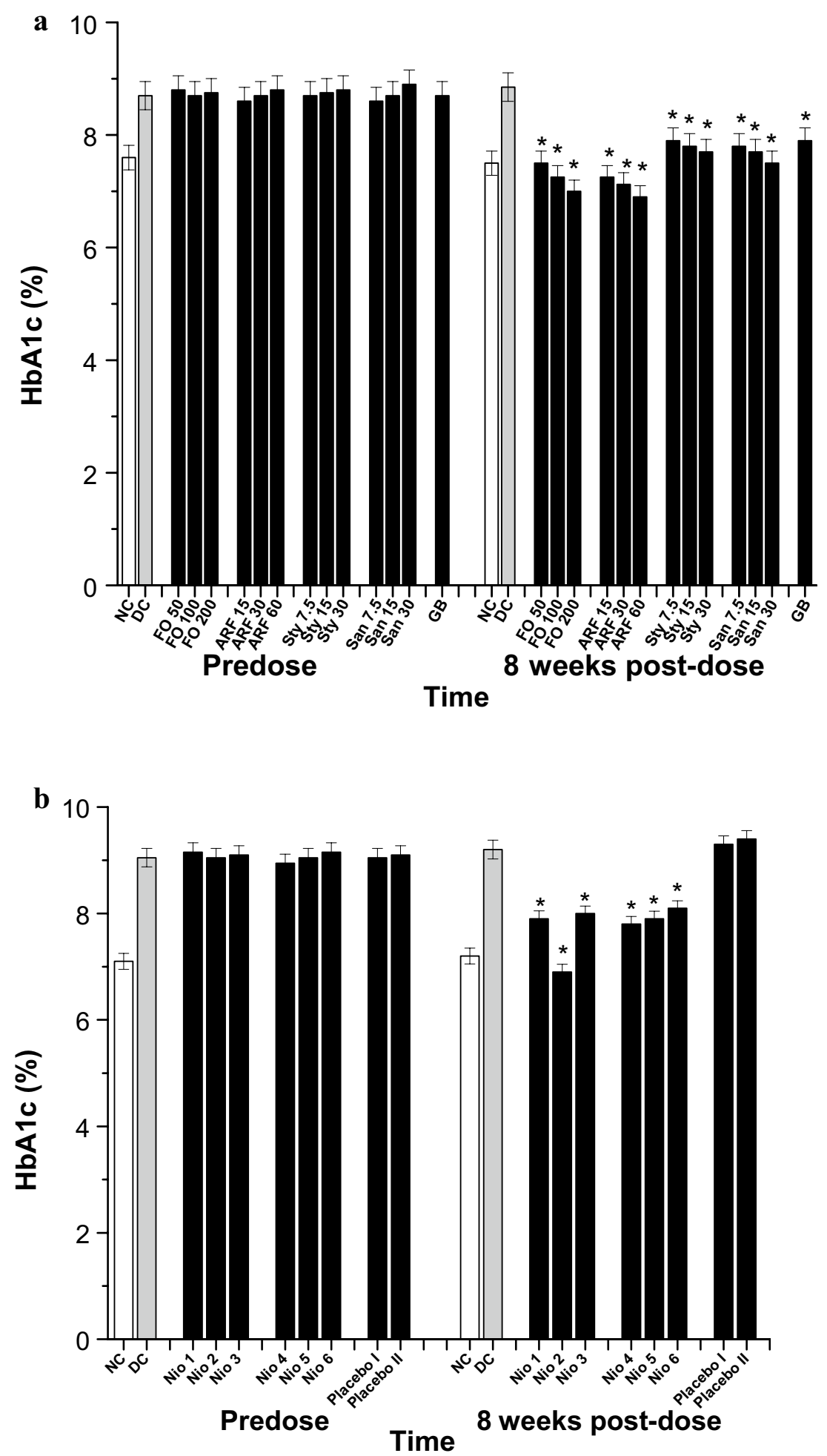

Fig. $8 \mathrm{HbA1c}(\%)$ analysis. All doses are in (mg/Kg). a The effects of FO, ARF, Sty and San various doses utilizing Glibenclamide $5 \mathrm{mg} / \mathrm{Kg}$ (GB) as a positive control. $\mathbf{b}$ The effects of Nio $1-6$ and placebo I and II. Asterisks designate significant results $(p<0.05)$ when compared to diabetic control (DC). NC designates normal non-diabetic control 

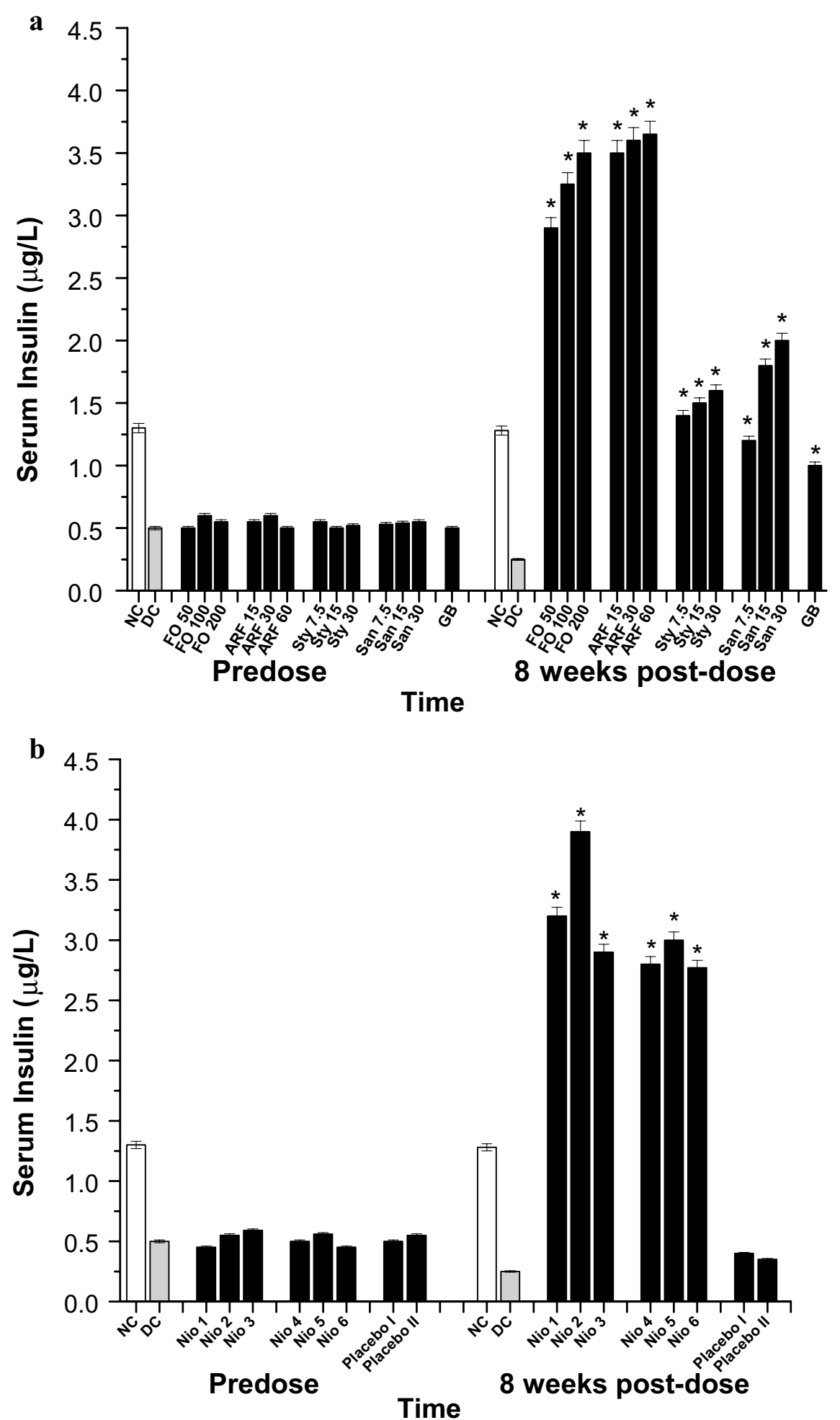

Fig. 9 Serum insulin ( $\mu \mathrm{g} / \mathrm{L})$. All doses are in ( $\mathrm{mg} / \mathrm{Kg}$ ). a The effects of FO, ARF, Sty and San various doses utilizing Glibenclamide $5 \mathrm{mg} / \mathrm{Kg}(\mathrm{GB})$ as a positive control. $\mathbf{b}$ The effects of Nio 1-6 and placebo I and II. Asterisks designate significant results $(p<0.05)$ when compared to diabetic control (DC). NC designates normal non-diabetic control 

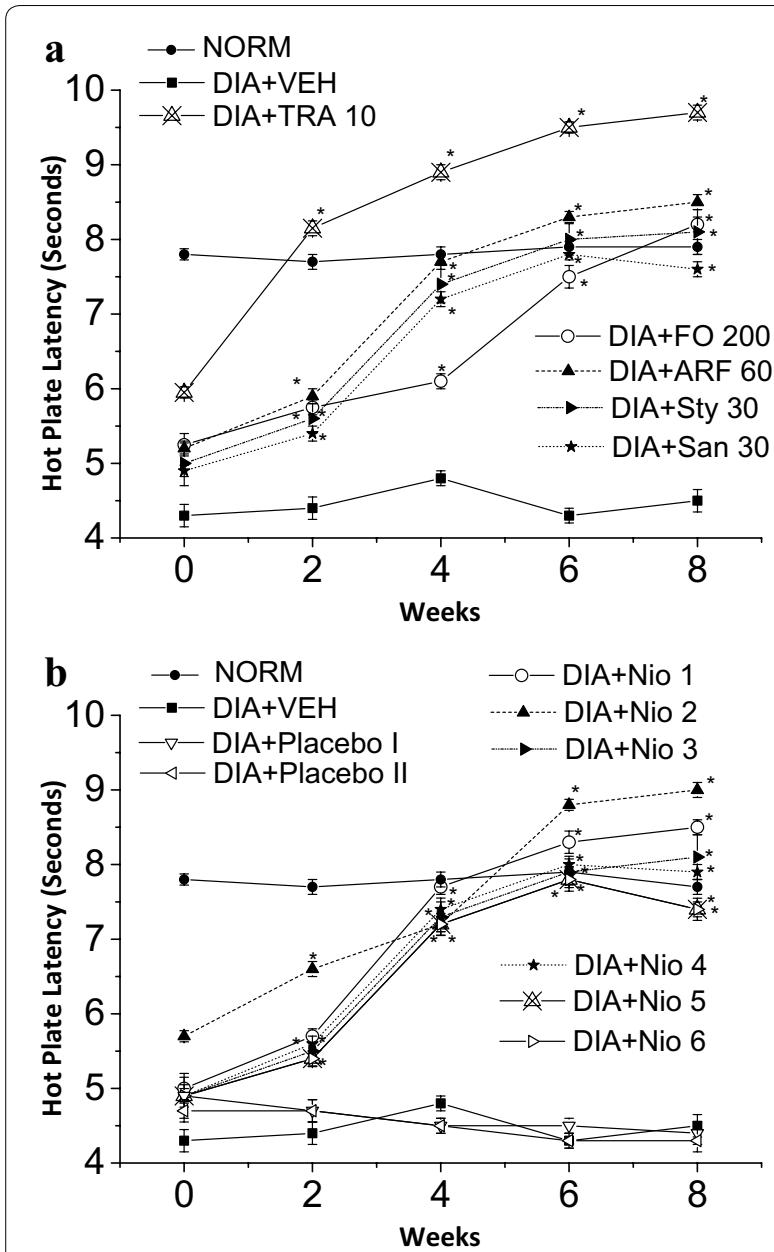

Fig. 10 Thermal hyperalgesia hot plate latency test. All doses are in $(\mathrm{mg} / \mathrm{Kg})$. a The effects of FO, ARF, Sty and San highest doses utilizing Tramadol $10 \mathrm{mg} / \mathrm{Kg}$ (TRA 10) as a positive control. b The effects of Nio $1-6$ and placebo I and II. Asterisks designate significant results ( $p<$ 0.05 ) when compared to diabetic control (DC). NC designates normal non-diabetic control

Moreover, Nio-1, Nio-2, Nio-3, Nio-4, Nio-5, and Nio-6 have shown ca. 88.89, 99.98, 79.98, 75.56, 73.33, and $71.11 \%$, respectively, improvement in hot-plate latency (Fig. 10b), and ca. 1.2, 2.2, 1.0, 0.8, 1.1, and 0.9 fold, respectively, improvement in tail-flick latency (Fig. 11b), 8 weeks post-administration. Placebo I and II did not show any significant changes in hot-plate and tail-flick latency experiments.

Compared to VEH, FO $(200 \mathrm{mg} / \mathrm{Kg})$, ARF $(60 \mathrm{mg} /$ $\mathrm{Kg})$, Sty $(30 \mathrm{mg} / \mathrm{Kg})$, and San $(30 \mathrm{mg} / \mathrm{Kg})$ highest doses have shown ca. $67.3,88.7,54.4,43.6$ fold, respectively, improvement in paw withdrawal thresholds (PWT) utilizing Von Frey filaments (Fig. 12), 8 weeks postadministration. These results showed that FO and ARF have significantly $(P<0.05)$ alleviated the mechanical

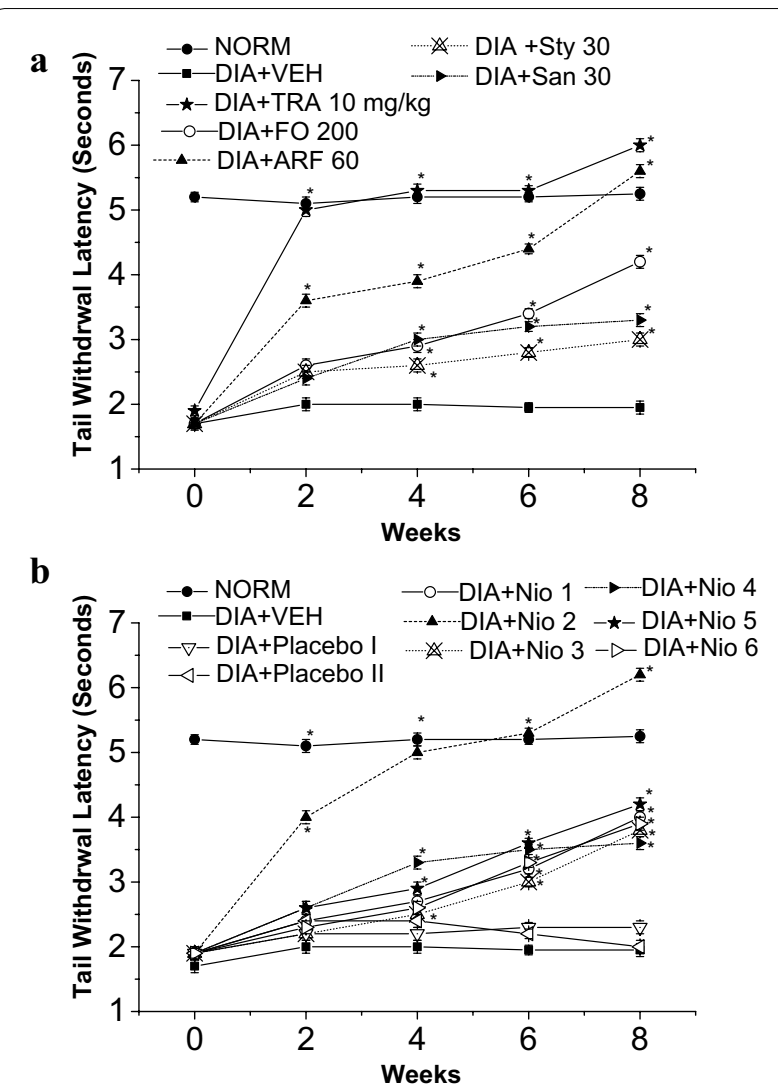

Fig. 11 Thermal hyperalgesia tail withdrawal latency test. All doses are in $(\mathrm{mg} / \mathrm{Kg})$. a The effects of FO, ARF, Sty and San highest doses utilizing Tramadol $10 \mathrm{mg} / \mathrm{Kg}$ (TRA 10) as a positive control. b The effects of Nio 1-6 and placebo I and II. Asterisks designate significant results $(p<0.05)$ when compared to diabetic control (DC). NC designates normal non-diabetic control

allodynia provoked by hyperglycemia, as demonstrated previously with analogous compounds [24]. Furthermore, Nio-1, Nio-2, Nio-3, Nio-4, Nio-5, and Nio-6 have shown ca. 58.7, 84.4, 58.6, 49.9, 58.6, and 59.5 fold, respectively, improvement in PWT (Fig. 12b), 8 weeks post-administration. Placebo I and II did not show any significant changes in PWT experiments (Table 4).

\section{Antinociceptive mechanism of action}

To explore the mechanism of actions underlying the tested compounds anti-diabetic neuropathy activities, the levels of the in vivo antioxidants (CAT, GSH, and LPO) serum levels were monitored for various diabetic-neuropathy groups prior to and 8 weeks post test compounds administration (Table 5). After 8 weeks of FO administration, FO $(50,100$, and $200 \mathrm{mg} / \mathrm{Kg}$ ) have shown $79.11,90.71$, and $104.33 \%$ increase in CAT levels, respectively (Table 5). Furthermore, ARF (15, 30 , and $60 \mathrm{mg} / \mathrm{Kg}$ ) have shown ca. 94.99, 99.59, and 

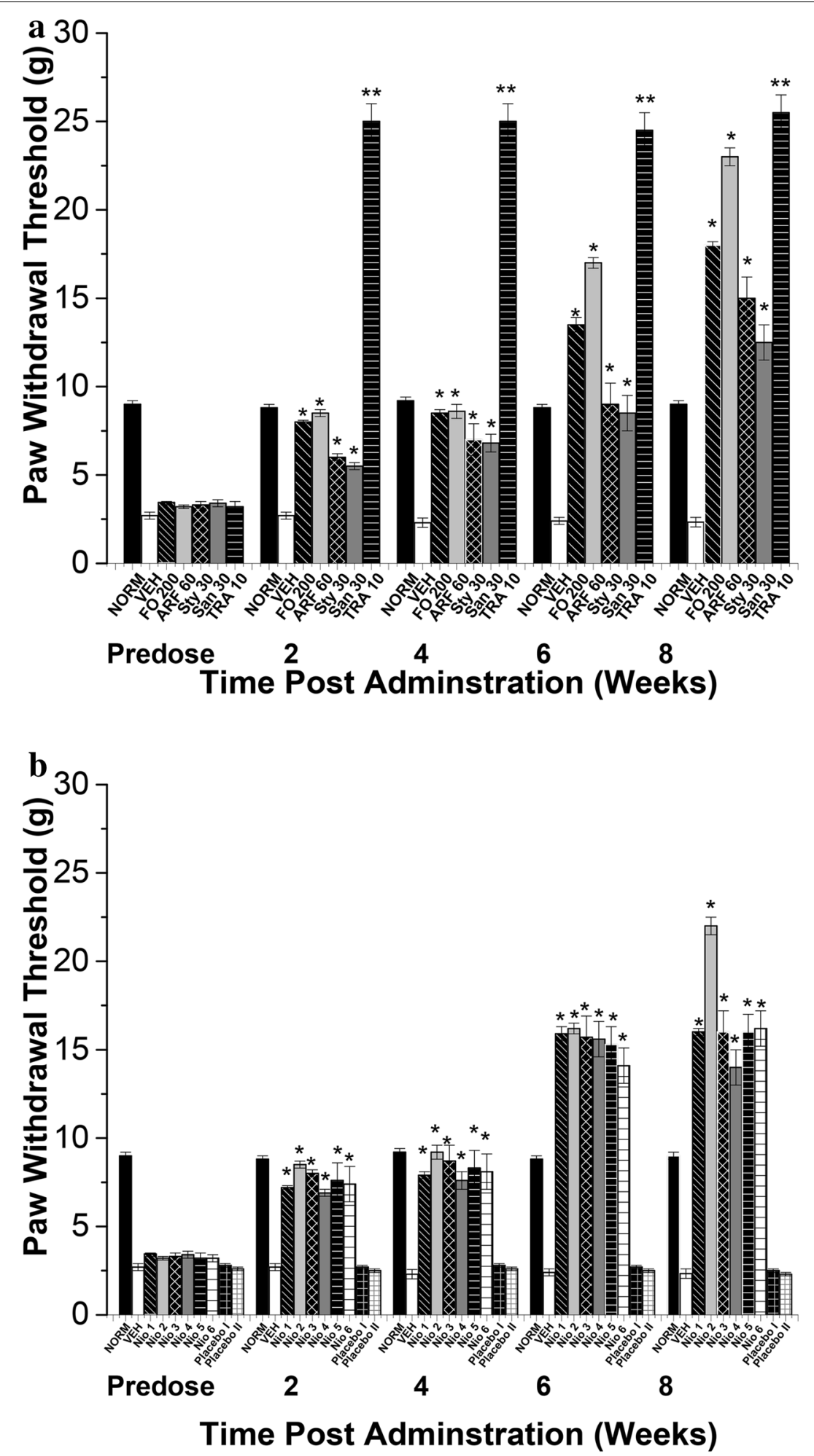

Fig. 12 Mechanical allodynia Von Frey test. All doses are in (mg/Kg). a The effects of FO, ARF, Sty and San highest doses utilizing Tramadol $10 \mathrm{mg} /$ $\mathrm{Kg}$ (TRA 10) as a positive control. b The effects of Nio 1-6 and placebo I and II. Asterisks designate significant results $(p<0.05)$ when compared to diabetic control (DC). NC designates normal non-diabetic control 
Table 4 Alpha-glucosidase and alpha-amylase inhibitory effects

\begin{tabular}{lcll}
\hline Group & Dose (mg/kg) & $\begin{array}{l}\text { Alpha-amylase } \\
\text { inhibition (\%) }\end{array}$ & $\begin{array}{l}\text { Alpha-glucosidase } \\
\text { inhibition (\%) }\end{array}$ \\
\hline FO & 50 & $32.18 \pm 1.75^{\mathrm{a}}$ & $49.12 \pm 1.05^{\mathrm{g}}$ \\
FO & 100 & $49.73 \pm 1.70^{\mathrm{b}}$ & $51.83 \pm 1.00^{\mathrm{h}}$ \\
FO & 200 & $63.78 \pm 1.31^{\mathrm{c}}$ & $71.48 \pm 1.01^{\mathrm{i}}$ \\
ARF & 15 & $33.15 \pm 1.46^{\mathrm{d}}$ & $54.44 \pm 1.06^{\mathrm{j}}$ \\
ARF & 30 & $53.63 \pm 1.56^{\mathrm{e}}$ & $56.36 \pm 1.03^{\mathrm{k}}$ \\
ARF & 60 & $69.23 \pm 1.43^{\mathrm{f}}$ & $74.33 \pm 1.07^{\mathrm{l}}$ \\
\hline
\end{tabular}

Values are shown as mean \pm S.E.M. $(\mathrm{n}=3)$.Values with different letters are significantly different $(p \leq 0.05)$

S.E.M. mean standard error

120.23\% increase in CAT levels, respectively, ca. 85.28 , $87.50,88.89 \%$ reduction in TBARS level, respectively, and ca. 37.36, 39.35, and $47.74 \%$ elevation in GSH levels, respectively (Table 5$)$. In addition, Sty $(7.5,15$, and $30 \mathrm{mg} / \mathrm{Kg}$ ) have shown $53.88,63.98$, and $69.78 \%$ increase in CAT levels, respectively, ca. 73.05, 73.61, $74.17 \%$ reduction in TBARS level, respectively, and ca. $24.35,25.52$, and $25.96 \%$ elevation in GSH levels, respectively, whilst that of San $(7.5,15$, and $30 \mathrm{mg} / \mathrm{Kg})$ have shown 59.03, 59.38, and $65.99 \%$ increase in CAT levels, respectively, ca. $74.17,75.28,76.39 \%$ reduction in TBARS level, respectively, and ca. 26.19, 26.26, and $28.75 \%$ elevation in GSH levels, respectively (Table 5). These results imply that FO and ARF have potential antioxidant activities combating the oxidative stress provoking the diabetic neuropathy [11]. Furthermore, these data have shown that FO and ARF anti-oxidative stress potentials and insulin-secretagogue long-term anti-diabetic activities might be responsible for their antidiabetic neuropathy potentials, as seen with similar natural products [45].

Moreover, Nio-1, Nio-2, Nio-3, Nio-4, Nio-5, and Nio-6 have shown ca. 89.51, 133.35, 99.59, 69.42, 79.87, and $74.57 \%$ increase in CAT serum levels, respectively, ca. $87.50,90.56,87.22,86.11,86.67$, and $84.44 \%$ reduction

Table 5 In vivo assessment of the antioxidant activities of Fumaria officinalis on CAT levels in serum, alterations in TBARS and reduced GSH (Mean \pm S.E.M., $n=7 /$ group)

\begin{tabular}{|c|c|c|c|c|c|c|c|}
\hline \multirow[t]{2}{*}{ Group } & \multirow[t]{2}{*}{ Dose (mg/kg) } & \multicolumn{2}{|c|}{ Catalase level (kU/I) } & \multicolumn{2}{|c|}{ TBARS Level (nM/100 g) } & \multicolumn{2}{|l|}{$\mathrm{GSH}(\mu \mathrm{g} / \mathrm{mg})$} \\
\hline & & Predose & 8th week & Predose & 8th week & Predose & 8th week \\
\hline NC & - & $30.77 \pm 1.66$ & $30.20 \pm 1.44$ & $0.73 \pm 0.02$ & $0.75 \pm 0.02$ & $64.40 \pm 1.10$ & $64.83 \pm 1.50$ \\
\hline DC & - & $21.28 \pm 1.20$ & $19.82 \pm 1.48$ & $1.15 \pm 0.02$ & $3.60 \pm 0.03$ & $57.30 \pm 1.70$ & $47.72 \pm 1.40$ \\
\hline$G^{a}$ & 5 & $21.42 \pm 1.11$ & $22.17 \pm 1.36$ & $1.17 \pm 0.02$ & $1.78 \pm 0.04$ & $56.70 \pm 1.60$ & $56.53 \pm 1.50$ \\
\hline $\mathrm{FO}^{\mathrm{a}}$ & 50 & $21.66 \pm 1.44$ & $35.50 \pm 1.25^{*}$ & $0.98 \pm 0.01$ & $0.58 \pm 0.02^{*}$ & $59.90 \pm 1.50$ & $64.9 \pm 1.50^{*}$ \\
\hline $\mathrm{FO}^{\mathrm{a}}$ & 100 & $21.98 \pm 1.23$ & $37.80 \pm 1.43^{*}$ & $1.02 \pm 0.01$ & $0.56 \pm 0.03^{*}$ & $59.00 \pm 1.60$ & $65.11 \pm 1.30^{*}$ \\
\hline $\mathrm{FO}^{\mathrm{a}}$ & 200 & $21.85 \pm 1.55$ & $40.50 \pm 1.37^{*}$ & $1.00 \pm 0.02$ & $0.54 \pm 0.04^{*}$ & $61.58 \pm 1.30$ & $65.50 \pm 1.40^{*}$ \\
\hline $\mathrm{ARF}^{\mathrm{a}}$ & 15 & $22.19 \pm 1.15$ & $38.65 \pm 1.55^{*}$ & $0.97 \pm 0.02$ & $0.53 \pm 0.01^{*}$ & $60.98 \pm 1.40$ & $65.55 \pm 1.40^{*}$ \\
\hline $\mathrm{ARF}^{\mathrm{a}}$ & 30 & $21.28 \pm 1.78$ & $39.56 \pm 1.70^{*}$ & $1.00 \pm 0.02$ & $0.45 \pm 0.01^{*}$ & $62.85 \pm 1.20$ & $66.50 \pm 1.10^{*}$ \\
\hline $\mathrm{ARF}^{\mathrm{a}}$ & 60 & $22.49 \pm 1.57$ & $43.65 \pm 1.31^{*}$ & $0.96 \pm 0.01$ & $0.40 \pm 0.02^{*}$ & $62.11 \pm 1.30$ & $70.50 \pm 1.10^{*}$ \\
\hline Sty & 7.5 & $21.42 \pm 1.25$ & $30.50 \pm 1.45^{*}$ & $1.15 \pm 0.02$ & $0.97 \pm 0.03^{*}$ & $60.60 \pm 1.20$ & $59.34 \pm 1.30^{*}$ \\
\hline Sty ${ }^{a}$ & 15 & $21.29 \pm 1.11$ & $32.50 \pm 1.34^{*}$ & $1.02 \pm 0.02$ & $0.95 \pm 0.03^{*}$ & $61.83 \pm 1.50$ & $59.90 \pm 1.40^{*}$ \\
\hline Sty ${ }^{\mathrm{a}}$ & 30 & $21.89 \pm 1.45$ & $33.65 \pm 1.05^{*}$ & $0.97 \pm 0.01$ & $0.93 \pm 0.01^{*}$ & $60.13 \pm 1.70$ & $60.11 \pm 1.50^{*}$ \\
\hline $\operatorname{San}^{\mathrm{a}}$ & 7.5 & $22.29 \pm 1.15$ & $31.52 \pm 1.13^{*}$ & $1.00 \pm 0.03$ & $0.93 \pm 0.03^{*}$ & $59.75 \pm 1.60$ & $60.22 \pm 1.80^{*}$ \\
\hline $\operatorname{San}^{\mathrm{a}}$ & 15 & $21.28 \pm 1.18$ & $31.59 \pm 1.56^{*}$ & $1.02 \pm 0.02$ & $0.89 \pm 0.02^{*}$ & $61.74 \pm 1.20$ & $60.25 \pm 1.90^{*}$ \\
\hline $\operatorname{San}^{\mathrm{a}}$ & 30 & $22.51 \pm 1.16$ & $32.90 \pm 1.50^{*}$ & $0.98 \pm 0.01$ & $0.85 \pm 0.02^{*}$ & $61.17 \pm 1.50$ & $61.44 \pm 1.70^{*}$ \\
\hline Nio $1^{\mathrm{a}}$ & 60 & $22.70 \pm 1.78$ & $37.56 \pm 1.77^{*}$ & $0.92 \pm 0.02$ & $0.45 \pm 0.02^{*}$ & $59.66 \pm 1.40$ & $63.22 \pm 1.40^{*}$ \\
\hline $\mathrm{NiO} 2^{\mathrm{a}}$ & 60 & $22.90 \pm 1.34$ & $46.25 \pm 1.45^{*}$ & $1.22 \pm 0.02$ & $0.34 \pm 0.02^{*}$ & $59.77 \pm 1.21$ & $75.55 \pm 1.10^{*}$ \\
\hline $\mathrm{NiO} 3^{\mathrm{a}}$ & 60 & $21.97 \pm 1.56$ & $39.56 \pm 1.33^{*}$ & $0.89 \pm 0.01$ & $0.46 \pm 0.02^{*}$ & $59.34 \pm 1.33$ & $65.66 \pm 1.10^{*}$ \\
\hline $\mathrm{NiO} 4^{\mathrm{a}}$ & 60 & $22.56 \pm 1.77$ & $33.58 \pm 1.45^{*}$ & $0.94 \pm 0.02$ & $0.50 \pm 0.01^{*}$ & $59.83 \pm 1.54$ & $62.99 \pm 1.40^{*}$ \\
\hline Nio $5^{a}$ & 60 & $22.89 \pm 1.44$ & $35.65 \pm 1.55^{*}$ & $1.01 \pm 0.01$ & $0.48 \pm 0.02^{*}$ & $60.13 \pm 1.70$ & $65.55 \pm 1.30^{*}$ \\
\hline Nio $6^{a}$ & 60 & $22.48 \pm 1.35$ & $34.60 \pm 1.45^{*}$ & $0.90 \pm 0.01$ & $0.56 \pm 0.01^{*}$ & $60.75 \pm 1.55$ & $63.88 \pm 1.40^{*}$ \\
\hline Placebo I & - & $22.45 \pm 1.33$ & $20.22 \pm 1.22$ & $1.11 \pm 0.01$ & $1.30 \pm 0.04$ & $62.98 \pm 1.40$ & $60.00 \pm 1.30^{*}$ \\
\hline Placebo II & - & $22.56 \pm 1.77$ & $19.20 \pm 1.46$ & $1.22 \pm 0.02$ & $1.45 \pm 0.04$ & $62.55 \pm 1.41$ & $59.33 \pm 1.20^{*}$ \\
\hline
\end{tabular}

S.E.M. mean standard error

* $p<0.05$ significant from the vehicle control animals

a Compared to vehicle control 
in TBARS level, respectively, and ca. 32.48, 58.32, 37.59, $32.00,37.36$, and $33.86 \%$ elevation in GSH levels, respectively (Table 5). Placebo I and II did not show any significant CAT, TBARS, or GSH serum changes (Table 5).

\section{Anti-inflammatory biological evaluation}

The anti-inflammatory potentials of FO, ARF, Sty, San, and various formulas were evaluated acutely via carrageenan-induced inflammatory-pain method (Fig. 13), and chronically via hind-paw edema method (Fig. 14), as previously done with analogous compounds [35] utilizing ibuprofen $100 \mathrm{mg} / \mathrm{Kg}$ (Ib) as a positive control (Figs. 13 and 14).

The acute carrageenan-induced inflammatory-pain method has shown that FO $(200 \mathrm{mg} / \mathrm{Kg})$, ARF $(60 \mathrm{mg} /$ $\mathrm{Kg})$, Sty $(30 \mathrm{mg} / \mathrm{Kg})$, and San $(30 \mathrm{mg} / \mathrm{Kg})$ highest doses have shown ca. 17.20, 24.00, 119.99, 115.89 fold, respectively, improvement in acute paw withdrawal thresholds in non-diabetic mice (Fig. 13). These results showed that FO and ARF have significantly $(P<0.05)$ ameliorated the acute carrageenan-induced inflammatory-pain provoked by carrageenan, as demonstrated previously with analogous compounds [46]. Moreover, Nio-1, Nio2, Nio-3, Nio-4, Nio-5, and Nio-6 have shown ca. 22.80, $27.98,25.87,19.60,23.99$, and 24.80 fold, respectively, improvement in acute paw withdrawal thresholds (Fig. 13). Placebo I and II did not show any significant changes in acute carrageenan-induced inflammatorypain experiments.

The chronic hind-paw edema method was performed utilizing a modified method described before [35]. The effect of the tested compounds potentials against chronic anti-inflammatory responses was also monitored (Fig. 14). FO (200 mg/Kg), ARF (60 mg/Kg), Sty (30 mg/ $\mathrm{Kg})$, and San $(30 \mathrm{mg} / \mathrm{Kg}$ ) highest doses have shown 82.72, $82.90,72.78,64.54 \%$, respectively, decrease in hind-paw edema utilizing MRPP plethysmograph (Fig. 14). These results showed that FO and ARF have significantly ( $P$ $<0.05)$ ameliorated the chronic hind-paw edema provoked by carrageenan, as demonstrated previously with similar natural phytochemicals $[35,45,46]$. In addition, Nio-1, Nio-2, Nio-3, Nio-4, Nio-5, and Nio-6 have shown $59.09,89.99,85.45,57.27,78.18$, and $75.46 \%$, respectively, decrease in hind-paw edema (Fig. 14). Placebo I and II did not show any significant changes in the chronic hindpaw edema experiments. These results implied that Nio 2 was the most efficient long-term anti-inflammatory formula ameliorating the chronic inflammatory symptoms.

\section{Anti-inflammatory mechanism of action}

To understand the anti-inflammatory mechanism of action attributed to F. officinalis and its active phytochemicals, the level of inflammatory-mediators was

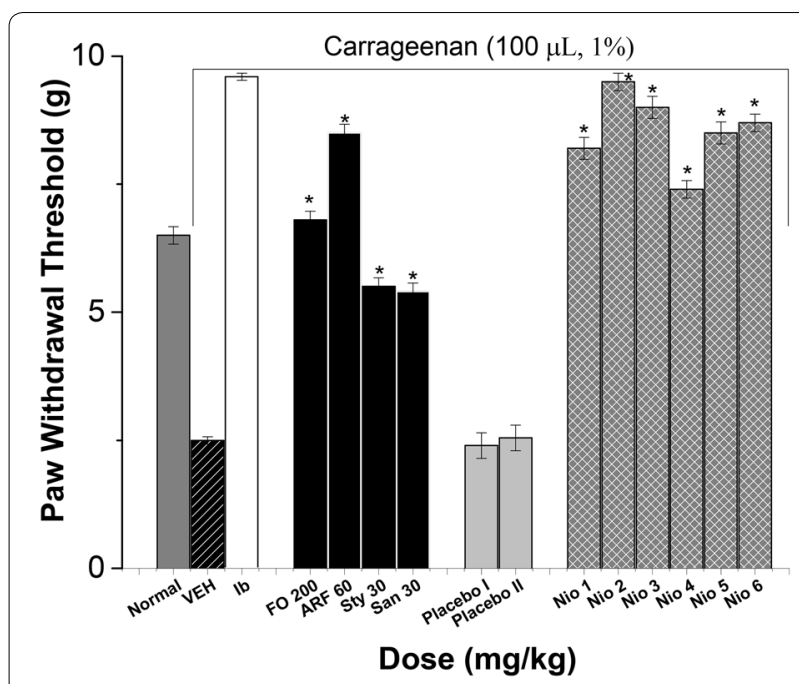

Fig. 13 The effect on acute inflammatory pain. All doses are in (mg/ $\mathrm{Kg}$ ) utilizing lbuprofen $100 \mathrm{mg} / \mathrm{Kg}(\mathrm{lb})$ as a positive control. Asterisks designate significant results $(p<0.05)$ when compared to vehicle control (VEH). Normal designates normal non-carrageenan treated control

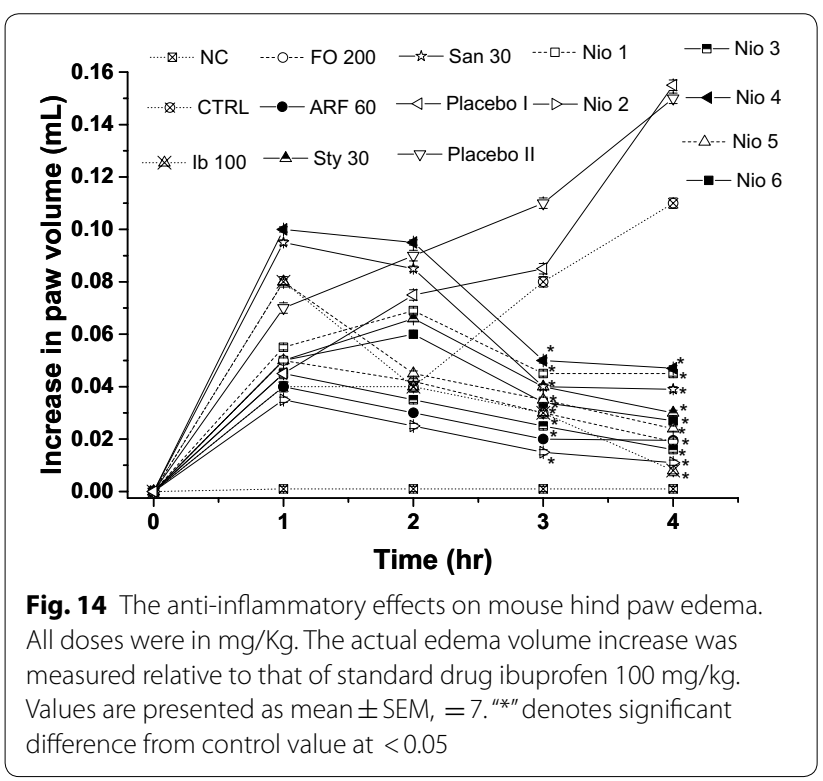

determined, as done before with similar natural products [47]. FO (200 mg/Kg), ARF (60 mg/Kg), Sty (30 mg/ $\mathrm{Kg})$, and San $(30 \mathrm{mg} / \mathrm{Kg}$ ) highest doses, and Nio 1-6 have reduced the levels of cytokines, diminished the levels of the pro-inflammatory cytokines TNF-alpha and IL-6, and elevated the anti-inflammatory factor IL-10 levels (Table 6). 


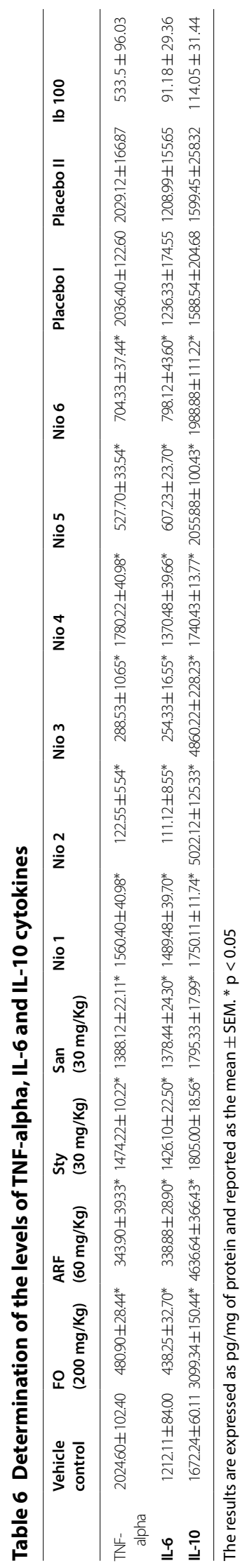




\section{Discussion}

Complementary medicine has grown attention in the past years due to their activities in improving humanhealth effectively, preventing ailments, lower side-effects, and lower costs when compared to conventional treatment [48]. Medicinal herbs are regularly employed to ameliorate different serious disorders like restoring metabolic balance and the management of inflammatory disorders [49]. Thus, phytochemical standardization, fractionation of herbs, isolation, identifying their active compounds responsible for their potentials, and their mechanism of action are crucial for today's medicine [45]. Moreover, identification and optimization of the pharmacokinetic-characters of herbal drugs are crucial for prediction, monitoring, and improving theirs in vivo biological activities [50]. Fumaria officinalis (F. officinalis, Papaveraceae) is an annual herb cultivated in Asia and Europe, known for its isoquinoline alkaloids and polyphenols [51]. In Asian folk medicine, the plant is known for its antioxidant properties and used in management of skin disorders, Alzheimer's disorder, cystitis, rheumatism, and arthritis [52]. Some preliminary experiments have been done exploring $F$. officinalis hypoglycemic activity utilizing in vitro protocols [5]. Nevertheless, this work is the first in-depth account of Fumaria officinalis bio-guided phytochemical investigation identifying its main active ingredients, optimizing their pharmacokinetics via various niosomal preparations to enhance their in vivo antineuropathic and anti-inflammatory potentials, and exploring their main mechanism of actions.

The progress in preparing niosomal novel drug delivery systems is a milestone in enhancing the efficacy of various conventional and complementary medicines via improving their pharmacokinetic properties [25].

The in vitro release pattern of the tested niosomes showed that Nio 2 had the fastest release, compared to other formulas (Fig. 4). Nio 2 has shown to have the most superior results related to the normalization of the acute BGL, when compared to FO, ARF, and other formulas. The subchronic and chronic results strengthen the acute findings, that Nio 2 was the most efficient antidiabetic agent when compared to FO, ARF, and other formulas. These results prove that Nio 2 is efficient in normalization of the BGL not only on short terms, but also on longer terms as seen with similar compounds $[24,29]$. Moreover, the insulin secretagogue investigation results prove that Nio 2 is the most efficient formula in their insulin-secretagogue potentials. Furthermore, the diabetic neuropathy results proved that Nio 2 was the most efficient formula combating diabetic hyperalgesia and diabetic mechanical allodynia, as demonstrated before [13, 27]. FO and ARF have shown a dose-dependent alpha-amylase and alpha-glucosidase inhibitory effects (Table 4). Additionally, the antioxidant data proved that Nio 2 is the most efficient in vivo antioxidant formula, and these antioxidant potentials together with their long-term hypoglycemic activities might be responsible for ameliorating diabetic neuropathy symptoms.

The anti-inflammatory results implied that Nio 2 was the most efficient anti-inflammatory formula ameliorating the acute inflammatory pain. Furthermore, the reduction of the pro-inflammatory TNF-alpha and IL-6, elevation the anti-inflammatory factor IL-10 levels, and amelioration of oxidative-stress might be the main mechanism responsible for their anti-inflammatory activities, as previously demonstrated [38, 46].

\section{Conclusion}

The current study strengthens the folk herbal medicine usage of Fumaria officinalis in acute and chronic pain, inflammation, and neuropathy. In-vivo bio-guided fractionation and chromatographic phytochemical analysis showed that the alkaloid-rich fraction (ARF) is the most active fraction and that ARF contained two major alkaloids; Stylopine 48.3\%, and Sanguinarine 51.6\%. In-vitro optimization, analytical, and in vivo biological investigations showed that Nio 2 was the most optimized niosomal formulation. This optimized niosome, Nio 2, worked by improving the pharmacokinetic properties of ARF developing adequate entrapment efficiency, rapid degradation, and acceptable stability in simulated GI conditions. FO, ARF, and Nio 2 are the most potent antidiabetic and anti-inflammatory compounds. Also the reduction of the pro-inflammatory TNF-alpha and IL-6, the elevation the anti-inflammatory factor IL-10 levels, and the amelioration of oxidative-stress might be the main mechanism responsible for their antinociceptive and anti-inflammatory activities. When correlating comparable concentrations, Nio 2 has shown superior efficacy compared to ARF. This study might offer a promising practical oral formulation ameliorating various inflammatory conditions and diabetic complications especially neuropathic-pain, for further research.

\section{Abbreviations}

F. officinalis: Fumaria officinalis; FO: Fumaria officinalis; GB: Glibenclamide; ARF: Alkaloid rich fraction; Nio 1-6: Niosome formulations 1-6; BGL: Blood glucose level; Sty: Stylopine; San: Sanguinarine; SEM: Standard error of mean; NC: Normal control; PDI: Poly-dispersity index; GSH: Reduced glutathione level; DC: Vehicle-treated diabetic control; HbA1c: Glycated hemoglobin; SIL: Serum insulin level; PWT: Paw withdrawal threshold; Ib: Ibuprofen; EE: Entrapment efficiency; CAT: Catalase serum level; TNF: Tumor necrosis factor; IL: Interleukin; RP: Reversed phase; ca.: Approximately; LPO: Lipid peroxidase; TBARS: Thiobarbituric acid reactive substances; TRA: Tramadol.

\section{Acknowledgements}

The authors would like to thank Mrs. G. Onsy for English proof-reading the manuscript. 


\section{Authors' contributions}

$\mathrm{KR}$ is the main author, contributed in the methodology and did all the experimental part, analyzed the data, wrote and revised the manuscript. SE contributed in the methodology and helped in writing and revising the manuscript. Both authors read and approved the final manuscript.

\section{Funding}

There is no funding to declare.

\section{Availability of data and materials}

The authors confirm that the data supporting the findings of this study are available within the article.

\section{Ethics approval and consent to participate}

Animal care for the research was done abiding by BAU Institutional Review Board regulations (2019A-0051-P-R-0341).

\section{Consent for publication}

Not applicable

\section{Competing interests}

The authors declare that they have no competing interests.

\section{Author details}

${ }^{1}$ Department of Pharmaceutical Sciences, Faculty of Pharmacy, Beirut Arab University, Beirut 115020, Lebanon. ${ }^{2}$ Department of Pharmaceutics and Pharmaceutical Technology, Faculty of Pharmacy and Drug Manufacturing, Pharos University in Alexandria, Alexandria, Egypt.

Received: 3 February 2020 Accepted: 23 April 2020

Published online: 01 May 2020

\section{References}

1. Raafat K. The top 100 phytoremedies and caregiving. 1st ed. Beirut: Dar Al-Nahda Al-Arabia; 2016.

2. Ivanov I, Vrancheva R, Marchev A, Petkova N, Aneva I, Denev P, Georgiev VG, Pavlov A. Antioxidant activities and phenolic compounds in Bulgarian Fumaria species. Int J Curr Microbiol Appl Sci. 2014;3(2):296-306.

3. Rakotondramasy-Rabesiaka L, Havet J-L, Porte C, Fauduet H. Solidliquid extraction of protopine from Fumaria officinalis L.- - analysis determination, kinetic reaction and model building. Sep Purif Technol. 2007;54(2):253-61.

4. Khamtache-Abderrahim S, Lequart-Pillon M, Gontier E, Gaillard I, Pilard S, Mathiron D, Djoudad-Kadji H, Maiza-Benabdesselam F. Isoquinoline alkaloid fractions of Fumaria officinalis: characterization and evaluation of their antioxidant and antibacterial activities. Ind Crops Prod. 2016;94:1001-8.

5. Fatima S, Akhtar MF, Ashraf KM, Sharif A, Saleem A, Akhtar B, Peerzada S, Shabbir M, Ali S, Ashraf W. Antioxidant and alpha amylase inhibitory activities of Fumaria officinalis and its antidiabetic potential against alloxan induced diabetes. Cell Mol Biol. 2019;65(2):50-7.

6. Orhan I, Şener B, Choudhary M, Khalid A. Acetylcholinesterase and butyrylcholinesterase inhibitory activity of some Turkish medicinal plants. J Ethnopharmacol. 2004;91(1):57-60.

7. Manske RH. The alkaloids of Fumariaceous plants: XVIII. Fumaria Officinalis L. Can J Res. 1938;16(12):438-44.

8. Soušek J, Guedon D, Adam T, Bochořáková H, Taborska E, Valka I, Šimánek V. Alkaloids and organic acids content of eight Fumaria species. Phytochem Anal. 1999;10(1):6-11.

9. Sturm S, Strasser E-M, Stuppner H. Quantification of Fumaria officinalis isoquinoline alkaloids by nonaqueous capillary electrophoresis-electrospray ion trap mass spectrometry. J Chromatogr A. 2006;1112(1-2):331-8.

10. Obrosova IG. Diabetic painful and insensate neuropathy: pathogenesis and potential treatments. Neurotherapeutics. 2009;6(4):638-47. https:// doi.org/10.1016/j.nurt.2009.07.004s1933-7213(09)00126-3.

11. Baynes JW, Thorpe SR. Role of oxidative stress in diabetic complications: a new perspective on an old paradigm. Diabetes. 1999;48(1):1-9.
12. Charnogursky G, Lee H, Lopez N. Diabetic neuropathy. Handb Clin Neurol. 2014;120:773-85. https://doi.org/10.1016/b978-0-7020-4087-0.00051 -6b978-0-7020-4087-0.00051-6.

13. Raafat K, El-Haj R, Shoumar D, Alaaeddine R, Fakhro Y, Tawil N, Shaer F, Daher A, Awada N, Sabra A, Atwi K, Khaled M, Messi R, Abouzaher N, Houri M, Al Jallad S. Neuropathic pain: literature review and recommendations of potential phytotherapies. Pharmacogn J. 2017:9(4):425-34.

14. Uttra AM, Alamgeer M, Shahzad A, Shabbir S. Jahan, Ephedra gerardiana aqueous ethanolic extract and fractions attenuate Freund Complete Adjuvant induced arthritis in Sprague Dawley rats by downregulating PGE2, COX2, IL-1ß, IL-6, TNF-a, NF-kB and upregulating IL-4 and IL-10. J Ethnopharmacol. 2018;224:482-96. https://doi.org/10.1016/j. jep.2018.06.018.

15. Sukketsiri W, Chonpathompikunlert P, Tanasawet S, Choosri N, Wongtawatchai T. Effects of Apium graveolens extract on the oxidative stress in the liver of adjuvant-induced arthritic rats. Prev Nutr Food Sci. 2016;21(2):79-84. https://doi.org/10.3746/pnf.2016.21.2.79pnfs-21-79.

16. Abdelkader $\mathrm{H}$, Alani AW, Alany RG. Recent advances in non-ionic surfactant vesicles (niosomes): self-assembly, fabrication, characterization, drug delivery applications and limitations. Drug Deliv. 2014;21(2):87-100.

17. Abdelbary G, El-gendy N. Niosome-encapsulated gentamicin for ophthalmic controlled delivery. AAPS PharmSciTech. 2008;9(3):740-7.

18. Arunothayanun P, Turton JA, Uchegbu IF, Florence AT. Preparation and in vitro/in vivo evaluation of luteinizing hormone releasing hormone (LHRH)-loaded polyhedral and spherical/tubular niosomes. J Pharm Sci. 1999;88(1):34-8.

19. Baillie A, Coombs G, Dolan T, Laurie J. Non-ionic surfactant vesicles, niosomes, as a delivery system for the anti-leishmanial drug, sodium stibogluconate. J Pharm Pharmacol. 1986;38(7):502-5.

20. Nasr M, Mansour S, Mortada ND, Elshamy AA. Vesicular aceclofenac systems: a comparative study between liposomes and niosomes. J Microencapsul. 2008;25(7):499-512. https://doi.org/10.1080/026520408020554 11792967635.

21. Azmin M, Florence A, Handjani-Vila R, Stuart J, Vanlerberghe G, Whittaker J. The effect of non-ionic surfactant vesicle (niosome) entrapment on the absorption and distribution of methotrexate in mice. J Pharm Pharmacol. 1985;37(4):237-42.

22. Kumar GP, Rajeshwarrao P. Nonionic surfactant vesicular systems for effective drug delivery - an overview. Acta Pharmaceutica Sinica B. 2011;1(4):208-19.

23. Bribi N, Algieri F, Rodriguez-Nogales A, Vezza T, Garrido-Mesa J, Utrilla MP, Del Mar Contreras M, Maiza F, Segura-Carretero A, Rodriguez-Cabezas ME, Galvez J. Intestinal anti-inflammatory effects of total alkaloid extract from Fumaria capreolata in the DNBS model of mice colitis and intestinal epithelial CMT93 cells. Phytomedicine. 2016;23(9):901-13. https://doi. org/10.1016/j.phymed.2016.05.003s0944-7113(16)30049-6.

24. Raafat K, El-Lakany A. Phytochemical and antinociceptive investigations of anemone coronaria active part ameliorating diabetic neuropathy pain PMIO. 2018;5(01):e5-13. https://doi.org/10.1055/s-0044-100148.

25. Arzani G, Haeri A, Daeihamed M, Bakhtiari-Kaboutaraki H, Dadashzadeh S. Niosomal carriers enhance oral bioavailability of carvedilol: effects of bile salt-enriched vesicles and carrier surface charge. Int J Nanomed. 2015;10:4797-813. https://doi.org/10.2147/ijn.s84703ijn-10-4797.

26. Raafat K, Habib J. Phytochemical compositions and antidiabetic potentials of Salvia sclarea L. essential oils. J Oleo Sci. 2018;67(8):1015-25. https ://doi.org/10.5650/jos.ess17187.

27. Raafat K, Wurglics M, Schubert-Zsilavecz M. Prunella vulgaris L. active components and their hypoglycemic and antinociceptive effects in alloxan-induced diabetic mice. Biomed Pharmacother. 2016;84:1008-18. https://doi.org/10.1016/j.biopha.2016.09.095.

28. Raafat K, El-Lakany A. Combination of rheum ribes and metformin against diabetes, thermal hyperalgesia, and tactile allodynia in a mice model. Altern Ther Health Med. 2017;23:138-48.

29. Raafat K, El-Darra N, Saleh FA, Rajha HN, Maroun RG, Louka N. Infraredassisted extraction and HPLC-analysis of Prunus armeniaca L. Pomace and detoxified-kernel and their antidiabetic effects. Phytochem Anal. 2017. https://doi.org/10.1002/pca.2723.

30. Cameron NE, Cotter MA. Pro-inflammatory mechanisms in diabetic neuropathy: focus on the nuclear factor kappa B pathway. Curr Drug Targets. 2008:9(1):60-7. 
31. Raafat K. Phytochemical analysis of Juglans regia oil and kernel exploring their antinociceptive and anti-inflammatory potentials utilizing combined bio-guided GC-FID, GC-MS and HPLC analyses. Revista Brasileira de Farmacognosia. 2018;28(3):358-68. https://doi.org/10.1016/j. bjp.2018.03.007.

32. Yasmineh WG, Kaur TP, Blazar BR, Theologides A. Serum catalase as marker of graft-vs-host disease in allogeneic bone marrow transplant recipients: pilot study. Clin Chem. 1995;41(11):1574-80.

33. Ellman GL. Tissue sulfhydryl groups. Arch Biochem Biophys. 1959;82(1):70-7.

34. Ohkawa H, Ohishi N, Yagi K. Assay for lipid peroxides in animal tissues by thiobarbituric acid reaction. Anal Biochem. 1979;95(2):351-8.

35. Boukhary R, Raafat K, Ghoneim Al, Aboul-Ela M, El-Lakany A. Anti-inflammatory and antioxidant activities of Salvia fruticosa: an HPLC determination of phenolic contents. Evid Based Compl Altern Med. 2016;2016:6. https://doi.org/10.1155/2016/7178105.

36. Gardmark M, Hoglund AU, Hammarlund-Udenaes M. Aspects on tail-flick, hot-plate and electrical stimulation tests for morphine antinociception. Pharmacol Toxicol. 1998;83(6):252-8.

37. Salama RAM, El Gayar NH, Georgy SS, Hamza M. Equivalent intraperitoneal doses of ibuprofen supplemented in drinking water or in diet: a behavioral and biochemical assay using antinociceptive and thromboxane inhibitory dose-response curves in mice. PeerJ. 2016;4:e2239. https ://doi.org/10.7717/peerj.2239.

38. Rozza AL, Meira de Faria F, Souza Brito AR, Pellizzon CH. The gastroprotective effect of menthol: involvement of anti-apoptotic, antioxidant and anti-inflammatory activities. PLoS ONE. 2014;9(1):e86686. https://doi. org/10.1371/journal.pone.0086686.

39. Khan MI, Madni A, Peltonen L. Development and in vitro characterization of sorbitan monolaurate and poloxamer 184 based niosomes for oral delivery of diacerein. Eur J Pharm Sci. 2016;95:88-95. https://doi. org/10.1016/j.ejps.2016.09.002.

40. Vasanth S, Dubey A, Ravi GS, Lewis SA, Ghate VM, El-Zahaby SA, Hebbar S. Development and investigation of vitamin C-enriched adapalene-loaded transfersome gel: a collegial approach for the treatment of Acne Vulgaris. AAPS PharmSciTech. 2020;21(2):61. https://doi.org/10.1208/s1224 9-019-1518-5.

41. Balakrishnan P, Shanmugam S, Lee WS, Lee WM, Kim JO, Oh DH, Kim D-D, Kim JS, Yoo BK, Choi H-G, Woo JS, Yong CS. Formulation and in vitro assessment of minoxidil niosomes for enhanced skin delivery. Int J Pharm. 2009;377(1):1-8. https://doi.org/10.1016/j.jpharm.2009.04.020.

42. Nasr A, Gardouh A, Ghorab M. Novel solid self-nanoemulsifying drug delivery system (S-SNEDDS) for oral delivery of olmesartan medoxomil: design, formulation, pharmacokinetic and bioavailability evaluation. Pharmaceutics. 2016. https://doi.org/10.3390/pharmaceutics8030020e20.
43. Hasan AA, Madkor H, Wageh S. Formulation and evaluation of metformin hydrochloride-loaded niosomes as controlled release drug delivery system. Drug Deliv. 2013;20(3-4):120-6. https://doi.org/10.3109/10717 544.2013.779332.

44. Raafat K. Combating diabetes and its emerging complications utilizing natural phytochemicals. Pharmacogn J. 2019;11(3):445-9.

45. Raafat K, El-Darra N, Saleh F, Rajha H, Louka N. Optimization of infraredassisted extraction of bioactive lactones from Saussurea lappa L. and their effects against gestational diabetes. Pharmacogn Mag. 2019;15(61):20818. https://doi.org/10.4103/pm.pm_380_18.

46. Raafat KM. Anti-inflammatory and anti-neuropathic effects of a novel quinic acid derivative from Acanthus syriacus. Avicenna J Phytomed. 2019 https://doi.org/10.22038/ajp.2019.12218.

47. Choi JH, Cha DS, Jeon H. Anti-inflammatory and anti-nociceptive properties of Prunus padus. J Ethnopharmacol. 2012;144(2):379-86. https://doi. org/10.1016/j.jep.2012.09.023.

48. Hassani FV, Shirani K, Hosseinzadeh H. Rosemary (Rosmarinus officinalis) as a potential therapeutic plant in metabolic syndrome: a review. Naunyn-Schmiedeberg's Arch Pharmacol. 2016;389(9):931-49. https:// doi.org/10.1007/s00210-016-1256-0.

49. Ramadan KS, Khalil OA, Danial EN, Alnahdi HS, Ayaz NO. Hypoglycemic and hepatoprotective activity of Rosmarinus officinalis extract in diabetic rats. J Physiol Biochem. 2013;69(4):779-83. https://doi.org/10.1007/s1310 5-013-0253-8.

50. Feng Y, Liu Z, Peng Y, Zhang L, Ju P, Bi K, Chen X. Validated LC-MS method for simultaneous quantitation of catalpol and harpagide in rat plasma: application to a comparative pharmacokinetic study in normal and diabetic rats after oral administration of Zeng-Ye-Decoction. Biomed Chromatogr. 2013;27(11):1503-10. https://doi.org/10.1002/bmc.2949.

51. Orhana I, Ozcelik B, Karaoglu T, Sener B. Antiviral and antimicrobial profiles of selected isoquinoline alkaloids from Fumaria and Corydalis species. Z Naturforsch C. 2007;62(1-2):19-26.

52. Chlebek J, Novák Z, Kassemová D, Šafratová M, Kostelník J, Malý L, Ločárek M, Opletal L, Hošt'álková A, Hrabinová M, Kuneš J, Novotná P, Urbanová M, Nováková L, Macáková K, Hulcová D, Solich P, Pérez Martín C, Jun D, Cahlíková L. Isoquinoline alkaloids from Fumaria officinalis L. and their biological activities related to Alzheimer's disease. Chem Biodivers. 2016;13(1):91-9. https://doi.org/10.1002/cbdv.201500033.

\section{Publisher's Note}

Springer Nature remains neutral with regard to jurisdictional claims in published maps and institutional affiliations.
Ready to submit your research? Choose BMC and benefit from:

- fast, convenient online submission

- thorough peer review by experienced researchers in your field

- rapid publication on acceptance

- support for research data, including large and complex data types

- gold Open Access which fosters wider collaboration and increased citations

- maximum visibility for your research: over 100M website views per year

At BMC, research is always in progress.

Learn more biomedcentral.com/submissions 